\title{
Climate regime and soil storage capacity interact to effect evapotranspiration in western United States mountain catchments
}

\section{E. S. Garcia ${ }^{1}$ and C. L. Tague ${ }^{2}$}

${ }^{1}$ University of California at Santa Barbara, Department of Geography, Santa Barbara, CA 93106-5131, USA

${ }^{2}$ University of California at Santa Barbara, Bren School of Environmental Sciences, Santa Barbara, CA 93106-5131, USA

Received: 1 February 2014 - Accepted: 6 February 2014 - Published: 25 February 2014 Correspondence to: E. S. Garcia (garcia@geog.ucsb.edu)

Published by Copernicus Publications on behalf of the European Geosciences Union.

Climate regime and soil storage capacity interact to effect ET

E. S. Garcia and C. L. Tague

Title Page

Abstract Introduction

Conclusions References

Tables Figures

14 $\rightarrow 1$

4

Back

Full Screen / Esc 


\section{Abstract}

In the winter-wet, summer-dry forests of the western United States (US), total annual evapotranspiration (ET) is largely a function of three separate but interacting properties: (1) climate, especially magnitude of precipitation, its partitioning into rain or snow, and snowmelt timing; (2) soil characteristics, including soil water holding capacity and rates of drainage; and (3) the total biomass where larger, more abundant vegetation is directly proportional to greater ET. Understanding how these controls influence ET in Mediterranean mountain environments is complicated by shifts between water and energy limitations both within the year and between years. We use a physically based process model to evaluate the strength of climate controls and soil properties in predicting ET in three snow-dominated, mountainous catchments in the western US. As we expect, statistical analysis shows that annual precipitation is a primary control of annual ET across all catchments. However, secondary climate controls vary across catchments. Further, the sensitivity of annual ET to precipitation and other climatic controls varies with soil characteristics. In the drier, more snow-dominated catchments ET is also controlled by spring temperature through its influence on the timing of snowmelt and the synchronicity between seasonal water availability and demand. In wetter catchments that receive a large fraction of winter precipitation as rainfall, the sensitivity to ET is also strongly influenced by soil water holding capacity. We show that in all catchments, soil characteristics affect the sensitivity of annual ET to climatic drivers. Estimates of annual ET become more sensitive to climatic drivers at low soil water holding capacities in the catchments with the stronger decoupling between precipitation and growing season demands.

\section{HESSD}

11, 2277-2319, 2014

Climate regime and soil storage capacity

interact to effect ET

E. S. Garcia and

C. L. Tague

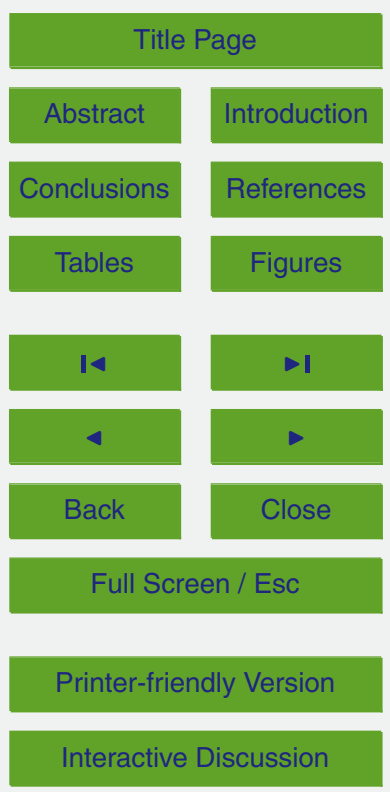




\section{Introduction}

Accurate estimation of evapotranspiration (ET) in the western US is complicated by interactions between the timing and magnitude of climatic drivers, landscape topographic features and vegetation distribution (Hamlet et al., 2007; Viola et al., 2008). In this re5 gion, forest ET is estimated to account for 30-80\% of the annual water budget (Baron and Denning, 1992; Jeton et al., 1996; Waichler et al., 2005) and water availability is considered to be its primary control (Boisvenue and Running, 2006). However, in the mountainous headwater catchments, much of the seasonal water availability is temporally disconnected from demands. This region's mountain watersheds receive a large fraction of their annual precipitation $(P)$ as snow in the winter. The magnitude and duration of snowpack varies geographically with climatic drivers such as gross precipitation and regional temperature patterns (Hamlet et al., 2005; Mote, 2006) and vegetation (Molotch et al., 2009; Varhola et al., 2010) and its melt is the primary source of water to headwater forest catchments and downstream municipalities in spring and summer (Bales et al., 2006). The steep topography within these catchments strongly controls $P$, temperature $(T)$, and their interaction (Daly et al., 1994) leading to variability in snowpack magnitude and duration and forest productivity across an elevation gradient (Bales et al., 2011; Goulden et al., 2012; Littell et al., 2008). This spatiotemporal variability in climatic interactions influencing water availability complicates our ability to understand how climate change will impact forest ET.

Warmer temperatures in the western US have affected hydrology through reductions in snowpack accumulation, due in part to precipitation falling as rain instead of snow (Knowles et al., 2006), and earlier occurrence of peak snowpack (Mote et al., 2005). These changes to winter precipitation shift seasonal water availability. Spring streamflow pulses are occurring up to four weeks earlier in the season (Stewart et al., 2005) which reduces plant water availability by drying out soils in the late growing season (Hamlet et al., 2007). Increased temperatures also effect plant responses through plant phenology shifting to earlier in the year (Cayan et al., 2001) which, in turn, may

\section{HESSD}

11, 2277-2319, 2014

Climate regime and soil storage capacity interact to effect ET

E. S. Garcia and

C. L. Tague

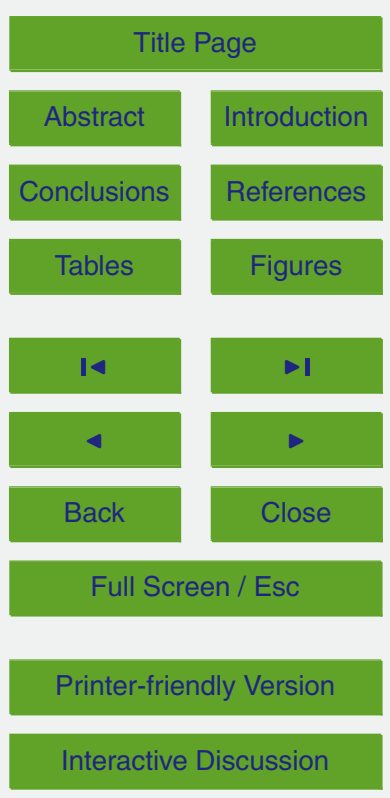


increase springtime productivity and extend the growing season. Though early season productivity may increase, the growing season is lengthened which can lead to soil water deficits later in the season. Soil dry-down reduces stomatal conductance and increases respiration costs which reduce overall productivity (Goldstein et al., 2000; $5 \mathrm{Hu}$ et al., 2010). These changes in water and energy inputs are expected to intensify (Ashfaq et al., 2013), and whether their interactions will increase or decrease ET remains uncertain.

Soil moisture characteristics have been shown to mitigate the effects of climate interactions on ET to varying degrees depending on precipitation regime (Hamlet et al., 2007; Porporato et al., 2004). In western US mountains, soil affects the timing of winter water availability into the growing season by two mechanisms: redistribution and storage. Steep topography extends plant water availability at lower elevations later into the growing season through lateral redistribution of snowmelt that recharges soil stores. Thus subsurface drainage can provide moisture to points on the landscape (i.e., riparian zones and swales) during seasonal summer drought, contributing to vegetation presence and enhancing ET (Hamlet et al., 2007; Hwang et al., 2011; Voepel et al., 2011). Modeling studies have highlighted that by including lateral redistribution of soil moisture, ET is more accurately captured in the Sierra Nevada (Lundquist, 2011; Tague and Peng, 2013) and in the Colorado Rockies (Litaor et al., 2008). Like snowpack, soil has the potential to act as a water reservoir, storing winter precipitation into the growing season (Geroy et al., 2011). However the amount of snowmelt captured and held by soil is strongly controlled by precipitation regime, snowpack dynamics, and soil characteristics. For example, Litaor et al. (2008) showed a positive correlation between amount of snowfall and soil moisture, with summer $P$ offsetting soil moisture depletion. In contrast, shallow soils in Idaho's Dry Creek Experimental Watershed did not have the capacity to capture enough snowmelt to have a large effect on ET (Smith et al., 2011). Because substantial heterogeneity in soil characteristics exists not just across, but also within mountain watersheds (Dahlgren et al., 1997; Denning et al., 1991; McGuire et al., 2007), we hypothesize that there is a resulting variability in soil

\section{HESSD}

11, 2277-2319, 2014

Climate regime and soil storage capacity interact to effect ET

E. S. Garcia and

C. L. Tague

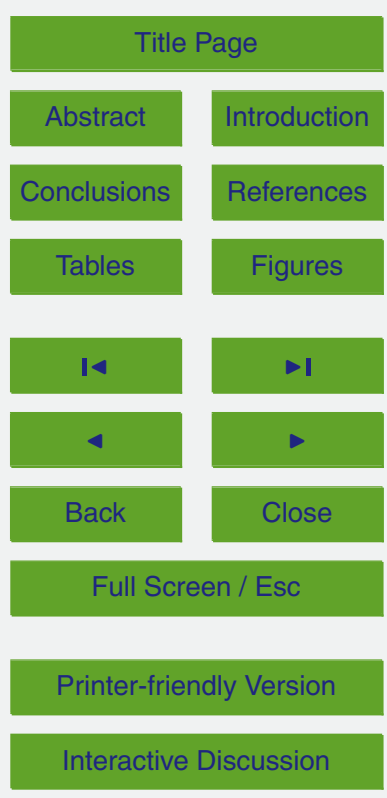


moisture conditions, leading to variable sensitivities to climate drivers within a watershed. Understanding the mechanistic controls of ET in western mountain watersheds requires disentangling climate drivers, their interactions and the effect of soil properties over spatially complex terrain. A spatially distributed, process-based model driven at 5 a sub-seasonal time step can explore watershed response to these climate drivers and changes in their seasonality.

In this paper, we explore how forest ET is constrained by several interacting controls that generally fall into the categories of water supply, water demand and the synchronicity between the two. We focus on two questions: how does the strength 10 of climate controls on ET differ across western US mountain watersheds of varying precipitation regimes? What is the influence of soil properties on the strength of these controls across these environments? We approach these questions with a processbased model capable of calculating soil moisture redistribution. We apply our model at a daily time step to three case study watersheds located in the western Oregon Cascades (OR-CAS), central Colorado Rocky Mountains (CO-ROC) and central California Sierras (CA-SIER). These watersheds receive a substantial fraction of precipitation as snowfall, but vary in their precipitation and temperature regimes and magnitude of snowpack relative to precipitation. In each watershed, we use linear regression to quantify the strength of annual precipitation, spring temperature, and the timing and magnitude of soil moisture recharge as controls on annual ET. We use sensitivity analysis to quantify how soil properties influence these relationships.

\section{Methods}

\subsection{Framework for primary controls on ET}

Our conceptual model of ET categorizes its controls as those affecting water demand or water availability (Fig. 1). Water demand, or potential ET (PET), is primarily controlled by radiation and total biomass; increasing either also increases annual PET.

\section{HESSD}

$11,2277-2319,2014$

Climate regime and soil storage capacity

interact to effect ET

E. S. Garcia and

C. L. Tague

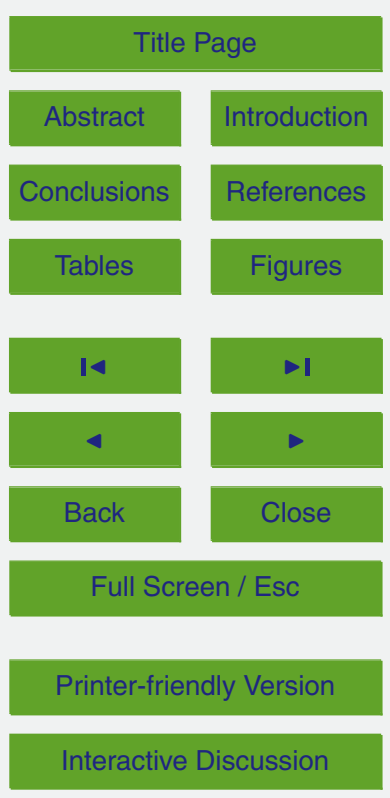


Water availability is influenced by both the magnitude of annual precipitation and the ability of a landscape to retain water, through soil water holding capacity and lateral moisture redistribution. The magnitude of annual precipitation, its seasonal distribution and, especially in the western US, its partitioning to rain or snow strongly influence 5 water supply. A key factor in meeting PET demands is the timing of water availability relative to timing of demand. Mediterranean climates are often characterized by a disconnect between seasonal water availability and growing season water demand when, for example, precipitation falls as rain in winter or snowmelt recharge occurs prior to onset of the growing season water demand.

10 Our conceptual model defines two distinct types of controls, climate and geology, that can directly alter this disconnect between water availability and demand. Firstly, climate varies the timing of precipitation events, transitions between snow and rain, and the timing and rate of snowmelt all of which can all alter the timing of soil moisture recharge. At the same time, climate (specifically temperature) can also alter water demand by extending the period over which high water demand occurs. Secondly, geologic and topographic properties of the landscape determine how much recharge is stored, and potentially allow water that falls earlier in the season to be available for ET at a later date. Soil available water capacity (AWC) is a landscape feature that is relatively constant through time. Larger AWC indicates that more water can be held in the soil. These soil moisture stores are replenished in the winter and drained by subsurface flow and ET. We expect that in Mediterranean environments ET will typically increase with higher AWC because more of the recharge will infiltrate into soil stores and be available for plants instead of being lost as runoff. Soil interacts with climate to extend plant water availability by capturing snowmelt, one of the primary sources of water for forest ET. If the rate of snowmelt allows for soil stores to be replenished later into the growing season, more of the winter precipitation is made available for plant water use. If, however, soils are too shallow to capture a significant amount of runoff or if the rate of rain or snowmelt inputs exceeds the rate of infiltration, then soil will have little ability to

\section{HESSD}

11, 2277-2319, 2014

Climate regime and soil storage capacity interact to effect ET

E. S. Garcia and

C. L. Tague

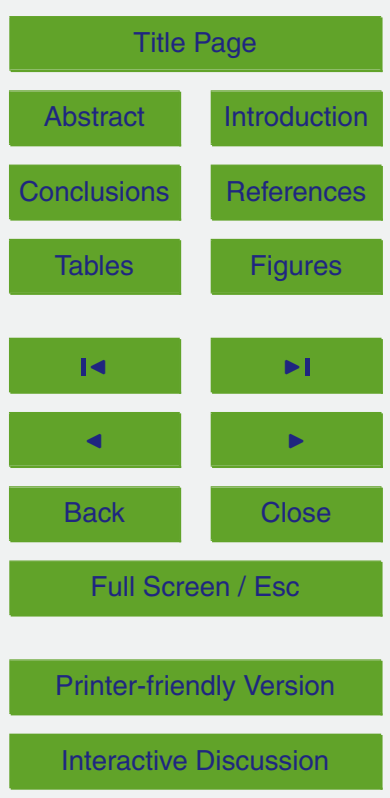


extend water availability. Therefore, soil potentially alters the effect of climate on ET, but the degree of that effect depends on regional climate drivers relative to soil properties.

Though this conceptual model relies on uncontroversial drivers of ET, it focuses on the importance of their interactions in space and time. Because water availability limits 5 ET, regional precipitation regime is a primary control of these interactions. Regional variation in the fraction of precipitation falling as snow can act as a first order effect on climate interactions with ET. Soil potentially changes climatic interactions to extend water availability and though its characteristics do not change over time, it is spatially variable both between and within watersheds. In order to address the strength of these 10 interactions, and their variability in different geoclimatic conditions, we use an ecohydrologic model that represents the relevant processes in our conceptual model.

\subsection{Model}

We use a physically based model, the Regional Hydro-Ecological Simulation System (RHESSys), to calculate vertical water, carbon and nitrogen fluxes in three watersheds 15 (Tague and Band, 2004). It is a spatially explicit model that partitions the landscape into units representative of the different hydro-ecological processes modeled (Band et al., 2000). The watershed delineates the largest unit and is divided into hillslopes, which drain to the stream via explicit subsurface routing. The smallest spatial unit, the patch, is the scale at which vertical soil moisture fluxes and carbon and nitrogen cycling 20 occurs. The model is more fully described in Tague and Band (2004), but as it is under continuous development we note that version 5.15 is used in this work.

RHESSys requires data describing spatial landscape characteristics and climate forcing; a digital elevation model (DEM), soil and vegetation maps are used to represent the topographic, geologic, carbon and nitrogen characteristics within a watershed.

MTN-CLM algorithms are used for extrapolation of climate processes (Running and Nemani, 1987) from point station measurements. Hydrologic processes modeled in RHESSys include interception, evapotranspiration, infiltration, vertical and lateral subsurface drainage, and snow accumulation and melt. The Penman-Monteith formula

\section{HESSD}

$11,2277-2319,2014$

Climate regime and soil storage capacity interact to effect ET

E. S. Garcia and

C. L. Tague

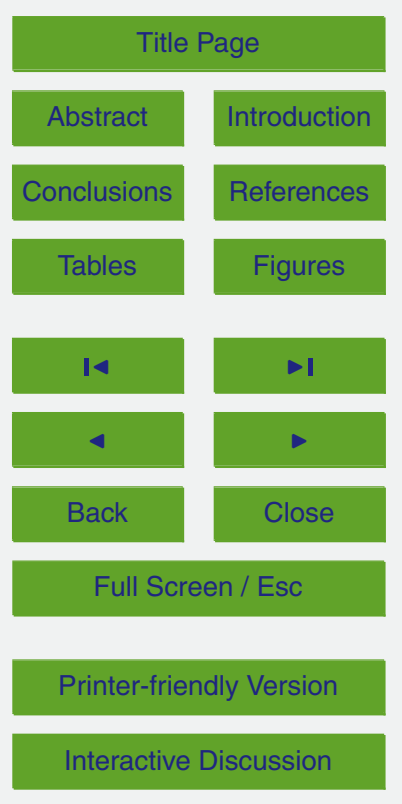


(Monteith, 1965) is used to calculate evaporation of canopy interception, snow sublimation, evaporation from soil and litter stores and transpiration by leaves. A model of stomatal conductance allows transpiration to vary with soil water availability, vapor pressure deficit, atmospheric $\mathrm{CO}_{2}$ concentration, and radiation and temperature 5 (Jarvis, 1976). A radiation transfer scheme that accounts for canopy overstory and understory, as well as sunlit and shaded leaves, controls energy available for transpiration. RHESSys accounts for changes in vapor pressure deficit for fractions of days that rain occurs (wet vs. dry periods). Plant canopy interception and ET are also a function of leaf area index (LAI) and gappiness of the canopy such that as LAI increases and 10 gap size decreases, plant interception capacity and transpiration potential increases. Soil water availability varies as a function of infiltration and water loss through transpiration, evaporation and drainage. RHESSys also routes laterally and thus patches can receive additional moisture inputs as either re-infiltration of surface flow or through shallow subsurface flow from upslope contributing areas. Lateral subsurface drainage routes subsurface and surface water between spatial units and is a function of topography, surface, soil and saprolite drainage characteristics. Deep groundwater stores are drained to the stream using a simple linear reservoir representation.

Carbon and nitrogen cycling in RHESSys was modified from BIOME-BGC (Thornton, 1998) to account for dynamic rooting depth, sunlit and shaded leaves, multiple canopy layers, variable carbon allocation strategies and drought stress mortality. The Farquhar equation is used to calculate gross primary productivity (GPP) (Farquhar et al., 1980). Plant respiration costs include both growth and maintenance respiration and are influenced by temperature following Ryan (1991). Net primary productivity (NPP) is calculated by subtracting total respiration costs from GPP.

25 In our three study sites (described in more detail below), RHESSys is driven with daily records of precipitation and maximum and minimum temperature. Each basin is calibrated for seven soil parameters that characterize subsurface drainage properties. Soil drainage rates are controlled by saturated hydraulic conductivity $(K)$ and its decay with depth $(m)$. Soil air-entry pressure $\left(\varphi_{\mathrm{ae}}\right)$, pore size index $(b)$, and rooting depth $\left(Z_{\mathrm{r}}\right)$

\section{HESSD}

11, 2277-2319, 2014

Climate regime and soil storage capacity interact to effect ET

E. S. Garcia and

C. L. Tague

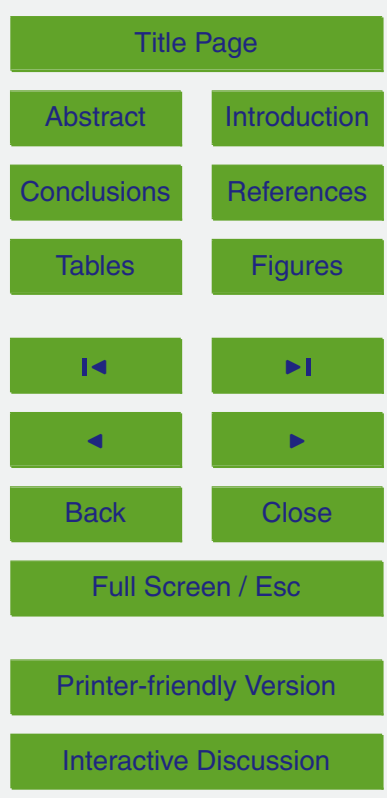


control soil water holding capacity (Brooks and Corey, 1964). In all basins, we assume that geologic properties allow for deeper groundwater stores that are inaccessible to vegetation (Table 2). These deep groundwater stores are controlled by two parameters representing the percentage of water that passes to the store $\left(\mathrm{gw}_{1}\right)$ and the rate of 5 its release to streamflow $\left(\mathrm{gw}_{2}\right)$. Calibration is conducted with a Monte-Carlo based approach, the generalized likelihood uncertainty estimation (GLUE) method (Beven and Binley, 1992). Parameter sets ( 800 total) are generated by random sampling from uniform distributions of literature-constrained estimates for the individual parameters.

We calibrate for soil parameters using two measures: daily streamflow statistics and 10 annual measures of NPP (Table 2). Streamflow statistics were set such that good soil parameters resulted in daily flow magnitude errors less than $15 \%$ and Nash-Sutcliffe efficiencies (a measure of hydrograph shape) greater than 0.65 (Nash and Sutcliffe, 1970). We use published forest field measurements of annual NPP to constrain parameters based on estimates of ecosystem productivity (values reported in Table 2).

\begin{abstract}
results of which are presented in Figs. 3-5. Results focusing on sensitivity across soil
\end{abstract}
We select a single soil parameter set to model daily hydrologic fluxes (Table 3), the parameters in each basin use the 800 calibration runs (Figs. 6-10).

\subsection{Application of the conceptual model in three western US basins}

\subsubsection{Geoclimatic metrics}

20 We use RHESSys to test the relative importance of both climate and geologic (storage) controls on ET as identified in our conceptual model. Model estimates of annual ET are used to examine the impact of average spring temperatures $\left(T_{\mathrm{AMJ}}\right)$, annual precipitation $(P)$, timing of soil water recharge $\left(R_{75}\right)$ and soil water holding capacity (AWC). We list all explanatory variables and their abbreviations in Table 1 for reference. In this paper, we exclude the effect of variable biomass and focus on mature canopies. The hydrologic response to changes in forest biomass is a complex and very active area of ecohydrologic research, especially in snowy forest environments (Lundquist et al.,

\section{HESSD}

11, 2277-2319, 2014

Climate regime and soil storage capacity interact to effect ET

E. S. Garcia and C. L. Tague

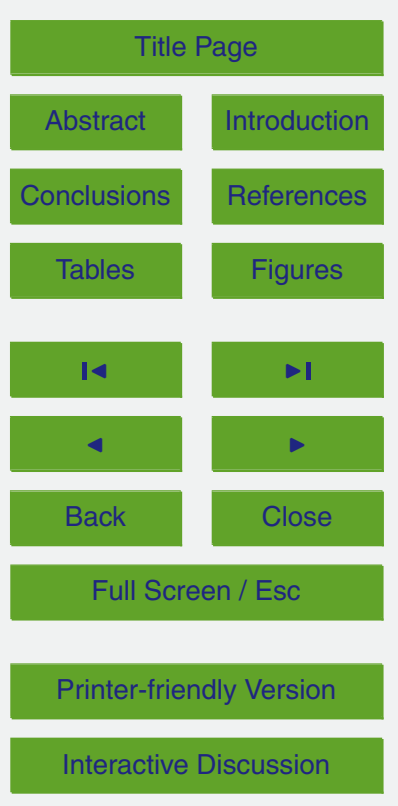


2013; Winkler et al., 2014). We note that future work will study the behavior of ET following disturbance that changes canopy structure on the landscape. Of the climatic metrics from our conceptual model, we focus on those that are most affected by climate change. We first examine the sensitivity of ET to climate drivers predicted to have 5 increasing variability, specifically precipitation and temperature. We then examine how soil water storage mediates the sensitivity of ET to climate drivers.

We used statistical analysis to identify a season when temperature most strongly influences estimates of annual ET modeled using historic climate. We performed linear regressions between total annual ET and 1 and 3 month averages of daily maximum $10 \quad\left(T_{\max }\right)$, minimum $\left(T_{\min }\right)$ and average temperatures $\left(T_{\text {avg }}=\left(T_{\max }+T_{\min }\right) / 2\right)$ for all watersheds and for all months of the year. We test the correlation significance with a $p$ value and set a threshold at 0.05 , i.e., a $p$ value greater than 0.05 is not significant. Our analysis found a three-month average of daily $T_{\text {avg }}$ in April, May and June $\left(T_{\text {AMJ }}\right)$ to have the greatest explanatory power as a temperature variable for estimating interannual variation in annual ET under historic climate variability across our three study watersheds (results not shown). We note that the $p$ value for $T_{\text {AMJ }}$ in our warmer watershed (OR-CAS) was greater than 0.05 so it is not reported as a significant result.

In these seasonally water-limited basins, we use total annual precipitation $(P)$ as a metric of gross climatic water input. Annual precipitation $P$ is summed over a water year (1 October to 30 September of the following calendar year). To assess the impact of timing of soil moisture recharge (as influenced either by year to year variation in the precipitation timing, snowmelt or rain-snow partitioning) we calculate $R_{75}$, the day of water year by which $75 \%$ of the total annual recharge has occurred. Recharge is defined as liquid water (e.g. rain throughfall or snowmelt) that reaches the soil surface. For becomes runoff, and water that infiltrates into the soil.

We examine the role of storage through soil available water holding capacity (AWC), calculated as the difference between soil field capacity and the plant wilting point. AWC represents the water stored in the soil after gravity drainage (field capacity) that can be

\section{HESSD}

11, 2277-2319, 2014

Climate regime and soil storage capacity interact to effect ET

E. S. Garcia and

C. L. Tague

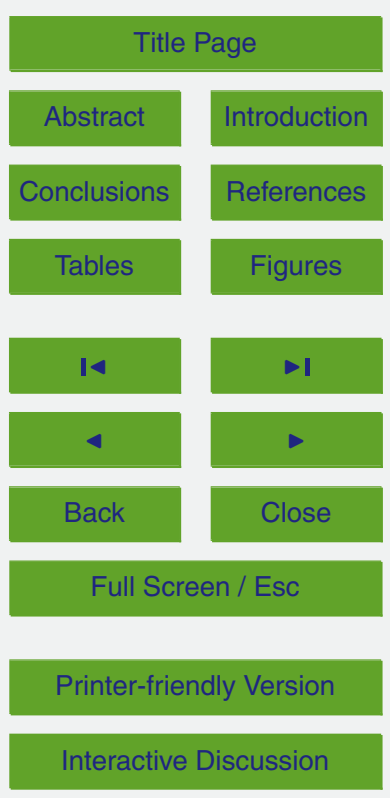


extracted by plant root suction (wilting point), and is thus still viable for plant water use (Dingman, 1994, p. 236). We calculate AWC as:

$$
\mathrm{AWC}=\left(\theta_{\mathrm{fc}}-\theta_{\mathrm{wp}}\right) Z_{\mathrm{r}}
$$

where $\theta_{\mathrm{fc}}$ represents the soil's field capacity per unit depth, $\theta_{\mathrm{wp}}$ the soil's character5 istic wilting point also per unit depth, and AWC is scaled by vegetation rooting depth, $Z_{\mathrm{r}}$, a model calibration parameter. The field capacity and wilting point are calculated, respectively, as

$\theta_{\mathrm{fc}}=\phi\left(\varphi_{\mathrm{ae}} / 0.033\right)^{b}$

${ }_{10} \theta_{\mathrm{wp}}=\phi\left(\varphi_{\mathrm{ae}} / \psi_{\mathrm{v}}\right)^{1 / b}$

where $\phi$ is soil porosity, $\varphi_{\text {ae }}$ represents the soil air-entry pressure (in meters), $b$ is a pore size distribution index that describes the soil moisture-characteristic curve, and $\psi_{\mathrm{v}}$ describes the pressure at which the plants' stomata close. Variables $\varphi_{\mathrm{ae}}$ and $b$ are also model calibration parameters. The range in soil parameter values is bounded by literature values specific to each site's soil properties (Dingman, 1994). This means all values of AWC calculated in calibration represent physically feasible soils for each watershed.

\subsubsection{Use of process model to test conceptual model}

The strength of these metrics of water availability and demand as controls on annual ET is quantified using linear regression analysis. We use RHESSys to calculate total annual ET in each basin over the entire available climate record (25-45 yr). We examine the controls on inter-annual variability of ET by regressing our climatic indicators $-P, T_{\mathrm{AMJ}}$, and $R_{75}$ - against total annual ET. We continue to use a threshold value of $p$ values less than 0.05 to determine significance. We then investigate how long-term 25 mean ET and its relationship with these climatic indicators are influenced by AWC. As noted above, all calibration parameter sets are physically viable representations of soils
HESSD

11, 2277-2319, 2014

Climate regime and soil storage capacity interact to effect ET

E. S. Garcia and C. L. Tague

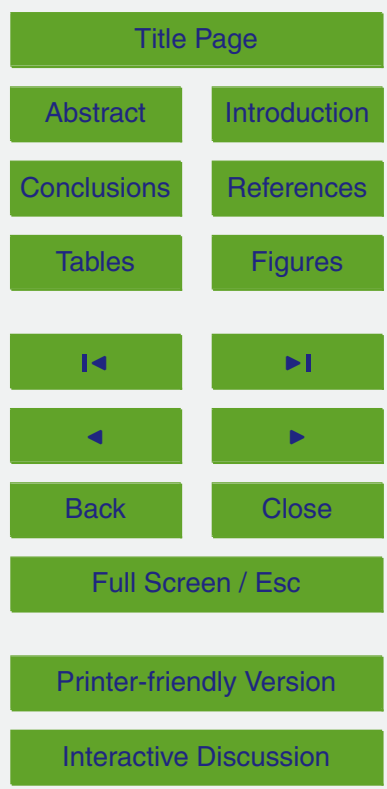


within each basin. In other words, though a single parameter set may not meet streamflow and annual NPP calibration metrics, that particular soil type may still exist within the basin. To examine how soil storage capacity may influence long term average ET, we average annual ET over our model calibration period (1985-2000) for each basin's 5800 soil calibration parameter sets. We compare this long-term average ET across AWC for each of these parameter sets to explore the role of soil storage capacity and how its impact differs across three watersheds with different precipitation/temperature regimes. To examine the influence of soil AWC on the relationship between our climate indicators and ET for each parameter set we calculate the slopes from regressing the 10 climate predictors $\left(P, T_{\mathrm{AMJ}}, R_{75}\right)$ against annual $\mathrm{ET}$ and then plot those slopes against the parameter sets' AWC.

\subsection{Study sites}

These analyses are conducted in three western US mountain catchments: Big Thompson in Colorado's Rocky Mountains (CO-ROC), Lookout Creek in Oregon's Western 15 Cascades (OR-CAS), and Sagehen Creek Experimental Forest in California's Northern Sierra Nevada (CA-SIER). Basin characteristics pertinent to modeling annual ET are listed in Table 2 and we highlight important similarities and differences here. All sites are located on steep, mountainous slopes and are dominated by forest cover. All basins have typical Mediterranean climates, on average receiving 54-81\% of their annual precipitation during the winter, $29-64 \%$ of the annual $P$ falls as snow, and they do not meet potential evaporative demand during the growing season (Fig. 2, Table 2). On average, OR-CAS is a much wetter basin and receives more than twice as much annual precipitation than CO-ROC and CA-SIER. Despite OR-CAS receiving more precipitation, a much lower fraction of that winter precipitation is received as snow, so is lost as runoff early in the water year (Fig. 2). The drier watersheds, CO-ROC and CA-SIER, receive more than half of their annual precipitation as snow (Table 2). CO-ROC also experiences a summer monsoonal season and on average receives $46 \%$ its annual precipitation from April-September. Landscape $\mathrm{C}$ and $\mathrm{N}$ stores in general vary with 2288

\section{HESSD}

11, 2277-2319, 2014

Climate regime and soil storage capacity interact to effect ET

E. S. Garcia and C. L. Tague

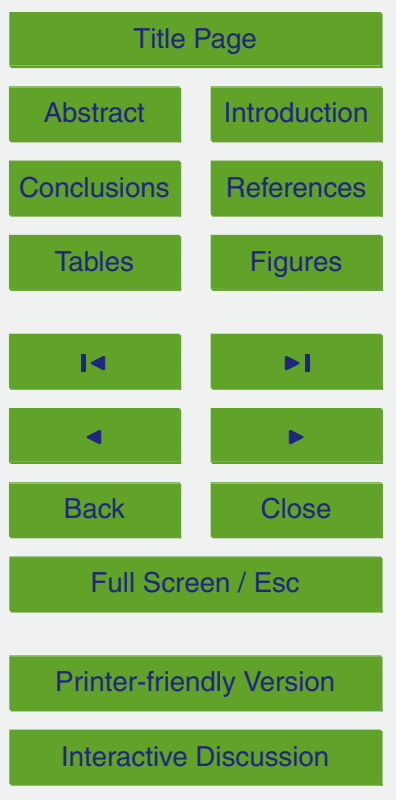


total annual $P$ across basins. For example, OR-CAS receives the most precipitation and also supports stands of large, old-growth forests; its LAI is more than twice that of either CO-ROC or CA-SIER. As presented in the model description (Sect. 2.1), we use a stable, climatic optimum for vegetation biomass for all analyses in this paper. Garcia 5 et al. (2013) and Tague et al. (2013) describe the soil and climate data, model vegetation and soil carbon store spin-up and calibration used for model implementations of OR-CAS and CA-SIER, respectively. Though RHESSys has previously been used in CO-ROC (Baron et al., 2000), we have made significant updates in RHESSys since that time, so we re-implemented the model as described in the next section.

\section{RHESSys model development for CO-ROC}

In CO-ROC, landscape topographic characteristics including elevation, slope and aspect were derived from a digital elevation model (DEM) downloaded from the US Geologic Survey (USGS) National Elevation Data set at 1/3 arc second resolution http://datagateway.nrcs.usda.gov/; accessed June 2011). A stream network was then derived so to accumulate surface and subsurface flow at USGS gage \#06733000. Subcatchments were delineated using GRASS GIS's watershed basin analysis program, r.watershed. Terrestrial data was aggregated such that the average size of the patch units, the smallest spatial units for calculation of vertical model processes, was $3600 \mathrm{~m}^{2}$. Soil classification data was downloaded from the Soil Survey Geographic database (SSURGO) and aggregated to four primary soil types: gravelly loam, sandy loam, loamy sandy and rock http://datagateway.nrcs.usda.gov/; accessed June 2010). Parameter values associated with these soil types are based on literature values (Dingman, 1994; Flock, 1978) and adjusted using model calibration, as described above. Vegetation land cover from the National Land Cover Database (NLCD) was imately $2700 \mathrm{~m}$, we use daily records of precipitation, $T_{\max }$, and $T_{\min }$ from two points within the watershed. RHESSys then interpolates data from these points based on
HESSD

$11,2277-2319,2014$

Climate regime and soil storage capacity interact to effect ET

E. S. Garcia and

C. L. Tague

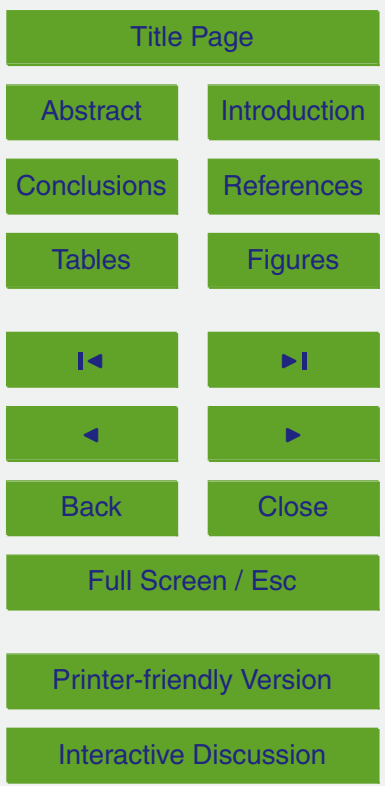


MTN-CLM (Running and Nemani, 1987) to provide spatial estimates of temperature, precipitation and other meterologic drivers for each patch. Climate data from 19802008 was downloaded from the DAYMET system for two locations - one at elevation $2460 \mathrm{~m}$ (latitude 40.35389 , longitude -105.58361 ) and the second at $3448 \mathrm{~m}$ (latitude 5 40.33769, longitude -105.70315) (Thornton and others, 2012).

Plant carbon $(\mathrm{C})$ and nitrogen $(\mathrm{N})$ stores were initialized by converting remotesensing derived LAl to leaf, stem and woody carbon and nitrogen values using allometric equations appropriate to the vegetation type http://daac.ornl.gov/MODIS/; MOD15A2 Collection 5; accessed June 2011). In order to stabilize soil C and N stores 10 relative to the LAI-derived plant $\mathrm{C}$ and $\mathrm{N}$, we run the model repeatedly over the basin's climate record until the change in stores stabilizes (Thornton and Rosenbloom, 2005). After stabilizing soil biogeochemical processes, we remove vegetation $\mathrm{C}$ and $\mathrm{N}$ stores and then dynamically "regrow" them using daily allocation equations (Landsberg and Waring, 1997) for $160 \mathrm{yr}$ in order to stabilize plant and soil $\mathrm{C}$ and $\mathrm{N}$ stores with model climate drivers. For all three basins, an optimum maximum size for each vegetation type was determined using published, field-derived estimates of LAI and aboveground and total annual NPP.

\section{Results}

\subsection{Annual $P$ vs. ET}

20 Not surprisingly, in all watersheds higher $P$ results in greater total annual ET (Fig. 3a). This is a significant relationship in the drier watersheds (CO-ROC and CA-SIER, Table 3) where the years of highest annual $P$ are correlated with the years of greatest annual ET. Of the three basins, CO-ROC's annual ET shows the greatest sensitivity to $P$, having the steepest slope (0.7). Annual $P$ is the strongest explanatory variable of annual ET in both CO-ROC $\left(r^{2}=0.88\right)$ and CA-SIER $\left(r^{2}=0.72\right)$ (Table 4, Fig. 3a). For CO-ROC, annual $P$ has a greater influence (steeper slope) in the dry years when
HESSD

$11,2277-2319,2014$

Climate regime and soil storage capacity

interact to effect ET

E. S. Garcia and

C. L. Tague

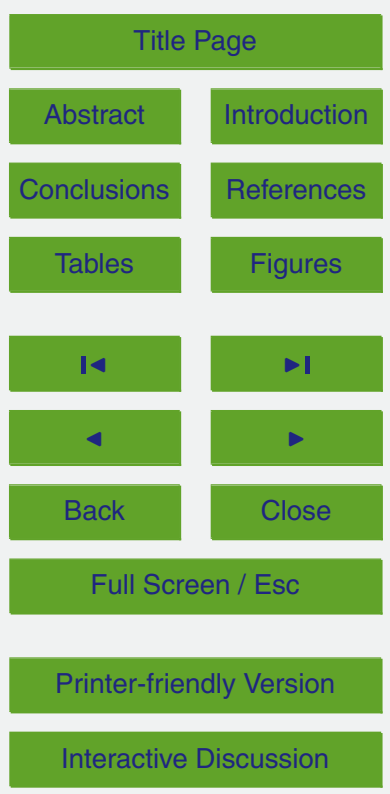


$P$ is less than $1000 \mathrm{~mm}$ (Fig. 3a). OR-CAS lacks a significant relationship between $P$ and ET on an annual scale. OR-CAS is a relatively wet basin and on average receives more than twice the amount of winter (January-March) precipitation than CA-SIER or CO-ROC. High annual $P$ in OR-CAS most years likely diminishes the sensitivity 5 of ET to magnitude of $P$. However, OR-CAS only receives $21 \%$ of its annual $P$ during the growing season, thus it is still water-limited during this period. The growing season is assumed to extend from 1 May to 1 October all watersheds. For OR-CAS, we find a significant relationship between ET and the precipitation that falls between July-September (Fig. 3b). A positive, but not significant, relationship between summer 10 precipitation and ET also occurs in CO-ROC where summer monsoonal pulses provide significant growing season soil moisture. CA-SIER has the smallest percentage of precipitation received during the growing season (19\% Table 2 ) and does not show a relationship between growing season precipitation and $\mathrm{ET}$.

\subsection{Timing of recharge vs. ET}

15 For all three catchments, later $R_{75}$ has a significant positive correlation with ET (Fig. 4). In OR-CAS and CA-SIER, $R_{75}$ is between February and May. There is more scatter in the predictive power of $R_{75}$ for annual ET when $R_{75}$ is early in the water year. The earliest $R_{75}$ are in OR-CAS, where a greater fraction of winter precipitation falls as rain. CA-SIER and CO-ROC are more sensitive to the timing of recharge than OR-

CAS. Summer monsoonal pulses in CO-ROC push $R_{75}$ to later in the water year as compared to OR-CAS or CA-SIER. The explanatory power of $R_{75}$ for ET is greatest in $\mathrm{CO}-\mathrm{ROC}$ where later days of recharge, due to later snowmelt and summer monsoons, can combine to provide soil moisture during peak growing season.

\subsection{Spring temperature vs. ET}

25 Warmer spring temperature $\left(T_{\mathrm{AMJ}}\right)$ in all basins generally reduces annual ET (Fig. 5a), which is somewhat counter-intuitive. Among the predicted consequences of increased
HESSD

$11,2277-2319,2014$

Climate regime and soil storage capacity

interact to effect ET

E. S. Garcia and

C. L. Tague

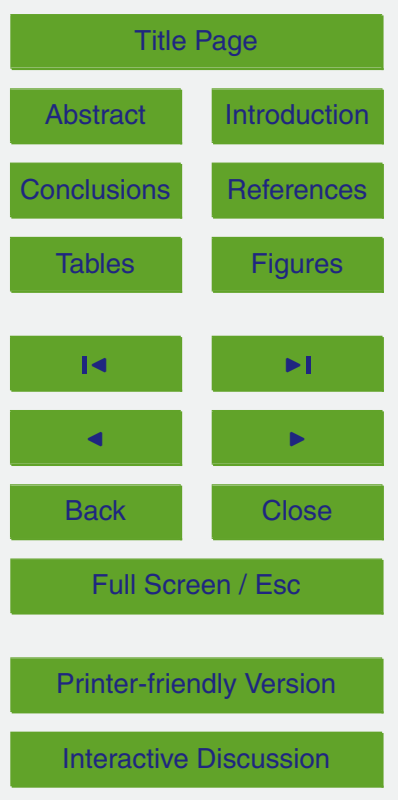


temperatures are an earlier start to the vegetation growing season (Cayan et al., 2001), and an increase in vapor pressure deficits and water demand (Isaac and van Wijngaarden, 2012). Thus warmer spring temperatures could potentially increase total annual ET through lengthening of the early growing season. However, warmer spring 5 temperatures are significantly correlated with lower ET in CO-ROC and CA-SIER. Our results suggest that the dominant effect of warmer spring temperatures is earlier meltout of snowpack, which leads to more snowmelt lost as runoff and results in less net recharge. So instead of higher $T_{A M J}$ leading to increased water demand and early growing season ET, in the two colder basins increasing $T_{\text {AMJ }}$ leads to a reduction

10 in water availability and a decline in later season ET. The relationship between spring air temperature and snowmelt timing is demonstrated by significant correlations between $T_{\mathrm{AMJ}}$ and $R_{75}$ for CO-ROC and CA-SIER (Fig. 5b), the two basins that receive a larger fraction of $P$ as snow and have cooler spring temperatures (Fig. 5, Table 2). The colder temperatures make these basins more sensitive in ET response to earlier snowmelt due to temperature increases. Conversely, OR-CAS which has warmer spring temperatures and receives less of its precipitation as snow (Table 2), does not show a significant relationship between $T_{\mathrm{AMJ}}$ and $\mathrm{ET}$.

\subsection{Soil AWC vs. ET}

As expected, increased soil available water capacity (AWC) increases the long-term 20 average ET in all basins. Figure 6 a shows a nonlinear relationship between long-term mean ET and AWC suggesting that the effect of increasing storage diminishes for higher AWC values. Each basin reaches an approximate storage capacity above which a further increase in storage (AWC) is less important and climate (i.e., $P$ and energy) variables limit ET. For each basin, we calculate that breakpoint value of AWC where 25 ET is less sensitive to AWC following Muggeo (2003). We find that the threshold value of AWC varies across basins and is higher in CO-ROC $(265 \mathrm{~mm})$ as compared to CASIER (195 mm) and OR-CAS (190 mm) (Fig. 6). Regression of logged values of AWC against annual ET show that a significant relationship exists in OR-CAS and CO-ROC

\section{HESSD}

11, 2277-2319, 2014

Climate regime and soil storage capacity interact to effect ET

E. S. Garcia and C. L. Tague

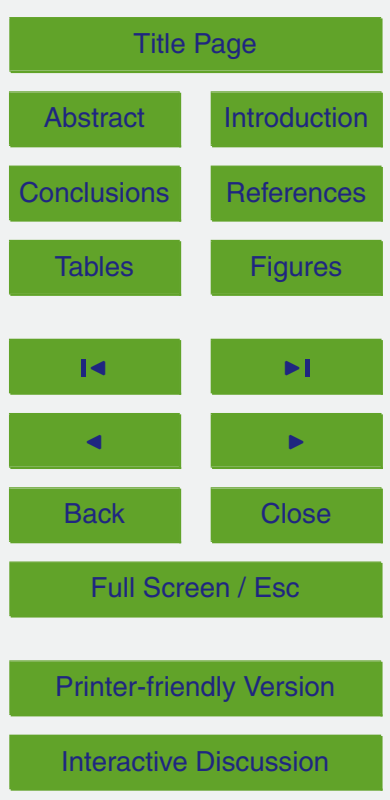


(Table 4). In CA-SIER there is substantially more scatter in the relationship between AWC and ET. We note that in this figure, each point refers to a separate simulation with a unique set of soil parameters impacting both local AWC for each patch and vertical and lateral drainage rates. In some cases, parameter sets may give the same AWC but 5 result in different drainage rates, affecting downslope lateral redistribution of moisture. For OR-CAS and CO-ROC these differences in soil parameters for a given AWC do not substantially alter ET. However in CA-SIER, we see greater sensitivity of ET to drainage parameters, even for the same AWC.

Lateral redistribution occurs for all three watersheds. However the topography of CA10

SIER results in many swale-like features that concentrate drainage from upslope areas. We calculate the topographic wetness index (TWI) using a $30 \mathrm{~m}$ resolution DEM for each watershed (Moore et al., 1991) (Table 2). The TWI reflects the propensity of a location to develop saturated conditions using the assumption that topography controls water flow. Higher TWI values represent flatter, converging terrain and lower values reflect steep topography. The mean TWI for CA-SIER is greater than, and significantly different from (Welch's $t$ test), the mean TWI for CO-ROC and OR-CAS. Particularly for CA-SIER, changing soil parameters associated with drainage rates can alter the timing of flow into areas that concentrate flow and subsequently alter their ET rates.

\subsection{Sensitivity of ET to climate drivers with soil AWC}

20 We analyze the sensitivity of ET relationships with climate drivers to soil properties by plotting the slope of linear regressions between ET and $P, R_{75}$, and $T_{\mathrm{AMJ}}$ across all soil parameters sets in Figs. 7-9, respectively. We note that AWC has been normalized in these plots to facilitate cross-site comparison. Because AWC is calculated as a function of soil storage characteristics and rooting depth (Eq. 2), soils with normalized AWC 25 greater than one represent soils that can hold more water relative to the basin average value.

\section{HESSD}

11, 2277-2319, 2014

Climate regime and soil storage capacity interact to effect ET

E. S. Garcia and C. L. Tague

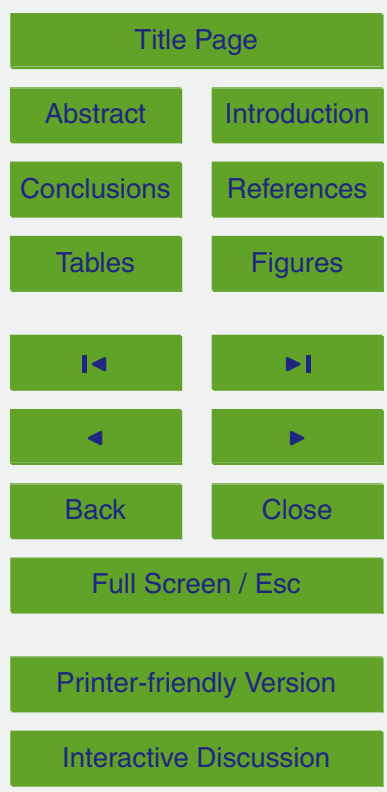




\subsubsection{Sensitivity to $P$ with AWC}

Of the climate drivers explored, annual precipitation $P$ has the greatest robustness across soil parameter sets, as suggested by number of sets that show a statistically significant relationship between annual $P$ and annual ET (Fig. 7). As expected, slopes

5 are positive between $P$ and ET across all basins. Only the drier basins CO-ROC and CA-SIER have $p$ values less than 0.001 , highlighting the strength of $P$ as a climatic driver in these drier basins, as discussed above. The response in slope sensitivity across AWC is similar in OR-CAS and CA-SIER where ET's sensitivity to $P$ is highest at low AWC and decreases with increased soil AWC. OR-CAS has a much smaller range in sensitivities (slope varies from 0.2-0.6) compared to CA-SIER (slope varies from 0.0-0.8). Thus in CA-SIER for low values of AWC, year-to-year variation in $P$ becomes a greater control on year-to-year variation in ET. For both OR-CAS and CASIER increasing AWC becomes less important at higher values of AWC. Higher scatter in slope of annual $P$ vs. ET relationship for CA-SIER also reflects the greater sensitivity of ET to soil parameters that influence lateral drainage as discussed above (Sect. 3.1). The variation of ET response to $P$ across AWC in CO-ROC is noteworthy for two reasons. First, CO-ROC has the narrowest range of slopes across AWC and has the highest values (0.6-0.8), which again reflects the consistency of annual $P$ as a control on inter-annual variation in ET in this basin. Second, unlike OR-CAS and CA-SIER, increasing AWC does not substantially reduce that sensitivity to $P$ (i.e., slope). We note that $\mathrm{CO}-\mathrm{ROC}$ has a seasonal precipitation regime where a significant fraction of its annual precipitation is received later in the growing season as summer monsoonal pulses. When precipitation occurs during the growing season, the water available for ET is less likely to be limited by storage capacity. Instead ET is limited by the amount or intensity of precipitation. Water that does recharge the system is used relatively quickly, making variation in storage (or AWC) less important as a control on how much $P$ can be used in CO-ROC.

\section{HESSD}

$11,2277-2319,2014$

Climate regime and soil storage capacity interact to effect ET

E. S. Garcia and

C. L. Tague

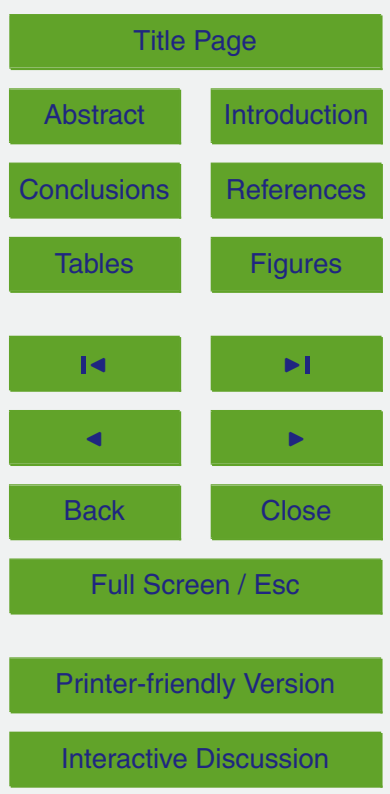




\subsubsection{Sensitivity to $R_{75}$ with AWC}

After precipitation, the timing of recharge $\left(R_{75}\right)$ most significantly correlates with increased ET across all AWC and all basins (Fig. 8). There are several similarities in the response of ET's sensitivity to $R_{75}$ across AWC when compared to sensitivity to $5 \quad P$ (Fig. 7). For example, the dry basins CO-ROC and CA-SIER have the highest degree of sensitivity (significant slopes $>1.0$ ) as compared to OR-CAS (slopes $<1.0$ ) and CA-SIER has the greatest variability in its sensitivity to AWC with slopes ranging from 1.0-3.0 across variation in soil parameters. CO-ROC once again has the least variability in the ET vs. $R_{75}$ relationship, with consistently high (2.0-2.5) slopes unaffected by 10 AWC.

\subsubsection{Sensitivity to $T_{\text {AMJ }}$ with AWC}

Finally, $T_{\text {AMJ }}$ has the fewest soil parameter sets with significant correlation with ET. None of the linear regressions of ET on $T_{\text {AMJ }}$ have statistical significance less than 0.001 (Fig. 9). The slopes are always negative because earlier melt results in less ET. 15 For all basins, the sensitivity of ET to $T_{\mathrm{AMJ}}$ is greatest at the lowest values of AWC, though CO-ROC once again demonstrates the least variability in slopes across the entire range of AWC (-0.2 to -0.3$)$. At OR-CAS, $T_{\mathrm{AMJ}}$ is only significant for the lower AWC values. We suggest this is in part due to the small fraction of $P$ that falls as snow. Because $T_{\text {AMJ }}$ 's largest effect is through timing of snowmelt (Fig. 5), AWC interacts with $20 T_{\text {AMJ }}$ to modulate the melt response. With relatively less snowmelt in OR-CAS, only the soils with the smallest capacities will have a significant negative interaction effect with AWC.

\section{Discussion}

Though forest ET in western US basins is controlled by water availability, it does not scale linearly with gross precipitation. Instead, water availability and forest ET in these 2295

\section{HESSD}

11, 2277-2319, 2014

Climate regime and soil storage capacity interact to effect ET

E. S. Garcia and C. L. Tague

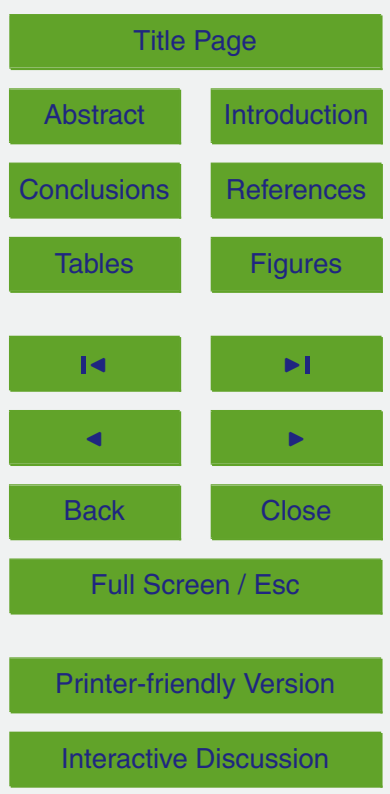


systems vary with climatic interactions that influence the timing of water delivery to forests relative to water demand and soil characteristics that control the storage of available water. We use a mechanistic model to calculate ET and linear regression models to quantify how separate geoclimatic metrics relating to water availability in 5 these regions - springtime temperature, total precipitation, and soil moisture capacity and recharge timing - affect forest ET under historic climate variability.

Our analysis uses an ecohydrologic model that has been validated by comparison against diverse observations in mountain environments, including streamflow and carbon flux. The model implements our current understanding of key energy, temperature and moisture controls on evaporative fluxes and their spatial-temporal patterns in complex topography of mountain environments. The model provides a simplified representation of these interactions, ignoring many additional complexities. For example, this study does not include key ecosystem characteristics such as species distributions or disturbances (i.e., fire, drought or insect outbreaks) that would influence productiv15 ity, evapotranspiration and their relationship with climate (Loudermilk et al., 2013). Our goal here is to focus on geophysical and climate effects on ET and use this analysis to highlight key sensitivities and reasons for differences in these sensitivities across the western US. Other top-down studies have adjusted Budyko curve relationships to address seasonality in $P$ and $T$ (Donohue et al., 2012; Feng et al., 2012), but do not account for the dynamics of snowmelt, soil storage and their interaction.

In our three western US headwater catchments, water availability, unsurprisingly, was a first order control of ET. In addition to total precipitation received, our analysis highlights the timing of water availability $\left(R_{75}\right)$ as a key predictor of $\mathrm{ET}$, showing that the strength of climatic controls influencing water availability changes with precipitation and temperature regimes. Key climatic differences in these catchments include total precipitation received, the fraction of precipitation that falls as snow, and the timing of soil moisture recharge (through snowmelt or summer precipitation pulses) relative to growing season water demands. Total annual $P$ is the first order control of ET in the two drier watersheds, CO-ROC and CA-SIER. OR-CAS, alternatively, does not have

\section{HESSD}

$11,2277-2319,2014$

Climate regime and soil storage capacity interact to effect ET

E. S. Garcia and

C. L. Tague

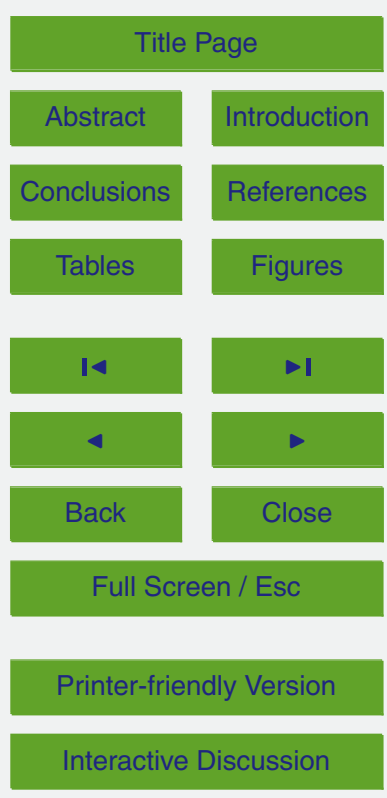


a statistically significant relationship between annual $P$ and annual ET. We suggest that this weak relationship in OR-CAS is due to the nature of comparing annual fluxes in a region that receives substantial precipitation as rain asynchronously to growing season demands (Fig. 2), i.e., PET demands are not met in OR-CAS because much 5 of the winter water pulse isn't stored as snowpack to be used through the length of the growing season.

In Mediterranean systems, the effectiveness of $P$ in increasing ET is greatest when it recharges the soil later in the water year, during the growing season and period of highest water demand. Previous work has shown seasonal increases in spring ET with 10 warmer spring temperatures (Hamlet et al., 2007). Our work shows that this is not always the case. Though early season ET may increase with warming temperatures, warmer spring temperatures may in some cases decrease total annual ET by reducing soil moisture replenishment in the later growing season. Snowpack acts as a storage mechanism that defers the release of $P$ into the growing season. Previous work has shown how timing of soil moisture recharge (Tague and Peng, 2013) and snowpack dynamics (Tague and Heyn, 2009; Trujillo et al., 2012) act as important controls of ET in the Sierra Nevada. Consequently, climate predictors related to snowmelt, $R_{75}$ and $T_{\mathrm{AMJ}}$, are important secondary controls of ET in the colder, snow-dominated watersheds, CASIER and CO-ROC. Spring temperature $T_{\text {AMJ }}$ is negatively correlated with ET, and is more strongly related to ET through its effect on snowmelt rather then by increasing evaporative demand during periods of greater water availability.

Soil affects ET by storing and releasing winter precipitation through the growing season and its effectiveness in increasing ET is a function of its storage capacity. In ORCAS, which has a modest snowpack compared to the other two watersheds, soil storage capacity (AWC) is the best predictor of total annual ET (Table 4). Our work shows soil AWC has the potential to affect the magnitude of ET (Fig. 6) and its sensitivity to climate drivers over both long-term and short-term climatic (annual to intra-annual) time scales. First, over a range of physically feasible basin average soil characteristics, long-term averages of ET increase with greater soil storage (AWC) in all basins. This

\section{HESSD}

$11,2277-2319,2014$

Climate regime and soil storage capacity interact to effect ET

E. S. Garcia and C. L. Tague

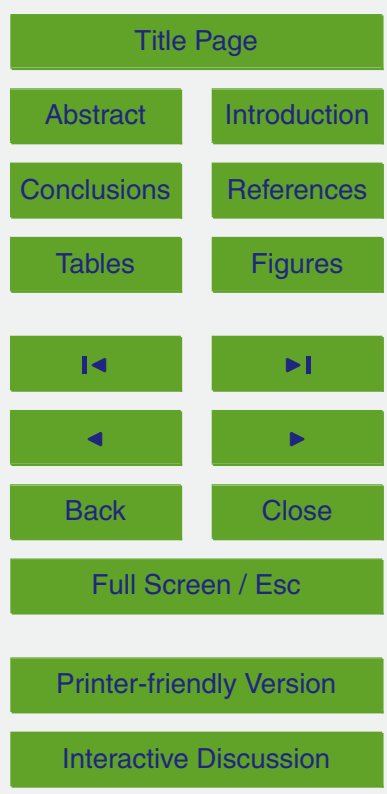


variation in ET associated with across (and possibly within) site AWC is on the same order of magnitude as inter-annual variation in ET with $P$. For example, ET in CO-ROC ranges from 380-600 $\mathrm{mm}$ across annual $P$ variation, and across all calibrated soil parameters long-term average ET ranges from $450-600 \mathrm{~mm}$. Similarly, in CA-SIER ET 5 ranges from $400-800 \mathrm{~mm}$ across the $P$ record and across all soil parameters its longterm ranges from $700-1000 \mathrm{~mm}$. The nonlinear relationship between ET and AWC suggests that below a threshold point in each basin (195-265 mm of AWC), long-term average ET is more sensitive to AWC and above these threshold values the effect of climate on ET is greater than an increase in soil storage.

10 An implicit control of ET in our soil representation is subsurface redistribution potential. Only a few studies have emphasized the role of lateral redistribution (Barnard et al., 2010; Tague and Peng, 2013). We argue, however, that modeling subsurface moisture redistribution makes larger soil AWC more effective in increasing ET because (1) captured recharge from snowmelt will be available to lower elevation forests and 15 (2) high elevation areas that redistribute soil moisture are depleted and able to capture recharge that would have been lost (i.e., through overland flow).

We show that soil can also substantially change the sensitivity of ET to year-to-year variability in climate drivers. $\mathrm{CO}-\mathrm{ROC}$ has a high sensitivity to climate drivers across all values of AWC. We suggest that a strong summer $P$ signal in CO-ROC explains the negligible change in ET's sensitivity to climate drivers across values of AWC, similar to other studies that show that summer $P$ can offset the dependence of ET on soil replenishment or winter snowpack (Hamlet et al., 2007; Litaor et al., 2008). However, the two basins receiving the smallest fraction of annual $P$ in the summer (CA-SIER and OR-CAS) have high sensitivities in ET's response to $P, R_{75}$, and $T_{\mathrm{AMJ}}$ at lower values of soil water content (AWC) but this sensitivity substantially decreases for higher AWC. The slope of the relationship between $P$ and ET decreases by more than $50 \%$ for both CA-SIER and OR-CAS at higher AWC. These results have important implications for understanding and ultimately predicting the spatial variability of ET within a basin. There is often little to no information about a basin's soil beyond coarse description of
HESSD

11, 2277-2319, 2014

Climate regime and soil storage capacity interact to effect ET

E. S. Garcia and

C. L. Tague

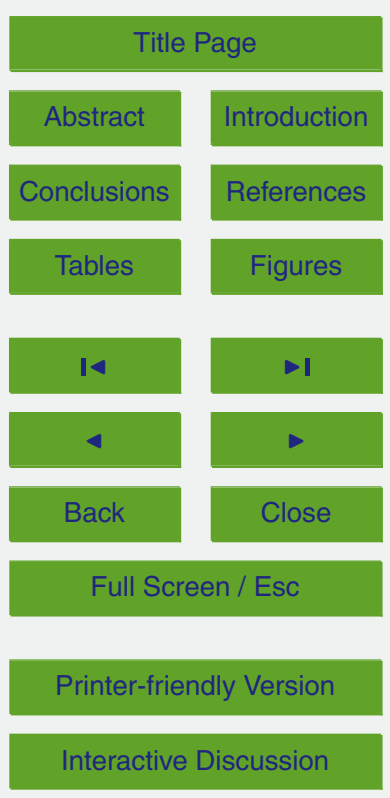


general characteristics; we have used that imperfect knowledge of soil characteristics to calculate a range of physically feasible values of AWC for each basin. Because there is substantial heterogeneity in soil characteristics within each basin (Dahlgren et al., 1997; Denning et al., 1991; McGuire et al., 2007) we might expect that the full 5 range of AWCs can be observed when we look at soils across individual forest stands within a basin. The effect of AWC is also as large as cross-basin differences in ET sensitivity. By normalizing slopes between climate drivers and ET across the range of AWC, we show that a similar sensitivity to $P$ and $T_{\text {AMJ }}$ can be achieved for all basins by varying soil AWC. For example, OR-CAS's stands with the smallest AWC are similarly 10 sensitive (slope of 0.6 ) to inter-annual variation precipitation as stands in CO-ROC (Fig. 7). This indicates potential for a high degree of ET heterogeneity within the basin due to soil properties, in addition to other landscape (elevation, aspect) and climatic drivers. It furthermore suggests that forests without a strong summer $P$ signal and with low AWC are more sensitive to climate drivers but the soils with higher AWC may buffer forest response to climate. In our example watersheds, OR-CAS and CA-SIER show the greatest sensitivity to climate perturbations in soils with lowest AWC.

As western US forests show increases in disturbance and mortality (Allen et al., 2010; Hicke et al., 2012), it becomes more important to understand these ecosystems' responses to primary climate drivers. The responses vary geographically with regional climate patterns, and our work also suggests that spatial heterogeneity in soils vary the strength of these drivers within and across watersheds as well. This understanding of how climate and soils combine to control ET can enhance our understanding of forest water stress related to increased mortality (van Mantgem et al., 2009). These findings may also extend to understanding of forest disturbances, providing mechanistic explanations for previous work showing that the area burned by wildfire can be correlated to ecosystems and their climates (Littell et al., 2009). Our process based modeling results call out specific climate measures that interact to reduce forest ET. These results emphasize the importance of interactions between several physical drivers and
HESSD

$11,2277-2319,2014$

Climate regime and soil storage capacity interact to effect ET

E. S. Garcia and

C. L. Tague

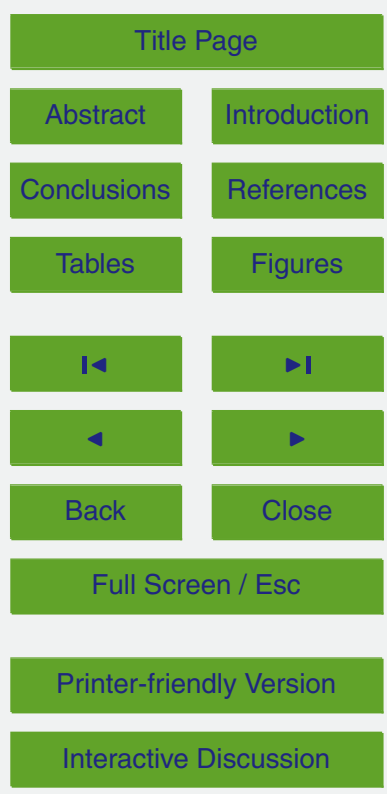


accentuate the need for introducing more field data to examine forest response and feedback in the face of climate change (Tague, 2009).

Acknowledgements. This work was supported by funding from the US Geological Survey through the Western Mountain Initiative (Award Number G09AC00337) and the US National 5 Science Foundation through the Willamette Watershed 2100 Project (Award Number EAR1039192). We also acknowledge support from the Center for Scientific Computing from the CNSI, MRL: an NSF MRSEC (DMR-1121053) and NSF CNS-0960316.

\section{References}

Allen, C. D., Macalady, A. K., Chenchouni, H., Bachelet, D., McDowell, N., Vennetier, M., Kitzberger, T., Rigling, A., Breshears, D. D., and Hogg, E. H.: A global overview of drought and heat-induced tree mortality reveals emerging climate change risks for forests, Forest Ecol. Manage., 259, 660-684, doi:10.1016/j.foreco.2009.09.001, 2010.

Arthur, M. and Fahey, T.: Biomass and nutrients in an Engelmann spruce - subalpine fir forest in north central Colorado: pools, annual production, and internal cycling, Can. J. Forest Res., $15 \quad 22,315-325$, doi:10.1139/x92-041, 1992.

Ashfaq, M., Ghosh, S., Kao, S.-C., Bowling, L. C., Mote, P., Touma, D., Rauscher, S. A., and Diffenbaugh, N. S.: Near-term acceleration of hydroclimatic change in the western US, J. Geophys. Res.-Atmos., 118, 1-18, doi:10.1002/jgrd.50816, 2013.

Bales, R. C., Molotch, N. P., Painter, T. H., Dettinger, M. D., Rice, R., and Dozier, J.: Mountain hydrology of the western United States, Water Resour. Res., 42, 8432, doi:10.1029/2005WR004387, 2006.

Bales, R. C., Hopmans, J., O'Green, A., Meadows, M., Hartsough, P., Kirchner, P., Hunsaker, C., and Beaudette, D.: Soil moisture response to snowmelt and rainfall in a Sierra Nevada mixedconifer forest, Vadose Zone J., 10, 786-799, doi:10.2136/vzj2011.0001, 2011.

Band, L. E., Tague, C. L., Brun, S. E., Tenenbaum, D. E., and Fernandes, R. A.: Modelling watersheds as spatial object hierarchies: structure and dynamics, Trans. GIS, 4, 181-196, doi:10.1111/1467-9671.00048, 2000.

Barnard, H., Graham, C., van Verseveld, W., Brooks, J. R., Bond, B. J., and McDonnell, J. J.: Mechanistic assessment of hillslope transpiration controls of diel subsurface flow: a steady- state irrigation approach, Ecohydrology, 3, 133-142, doi:10.1002/eco.114, 2010.

2300

\section{HESSD}

$11,2277-2319,2014$

Climate regime and soil storage capacity

interact to effect ET

E. S. Garcia and

C. L. Tague

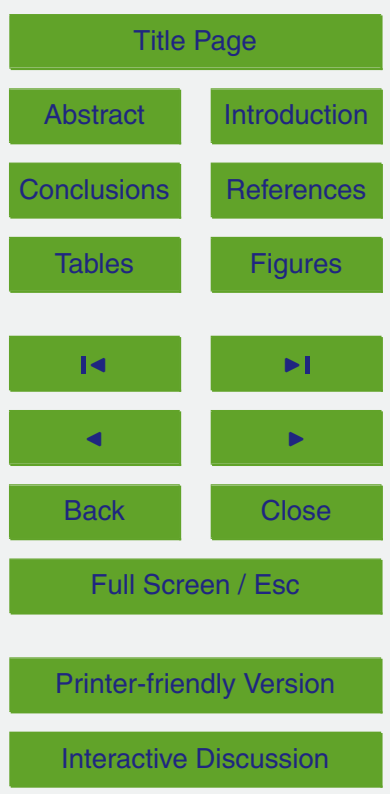


Baron, J. S. and Denning, A.: Hydrologic budget estimates, in: Biogeochemistry of a Subalpine Ecosystem, edited by: Baron, J., Springer-Verlag, New York, 28-47, 1992.

Baron, J. S., Hartman, M., and Band, L.: Sensitivity of a high-elevation Rocky Mountain watershed to altered climate and $\mathrm{CO}_{2}$, Water Resour. Res., 36, 89-99, 2000.

5 Beven, K. J. and Binley, A.: The future of dsitributed models: model calibration and uncertainty prediction, Hydrol. Process., 6, 279-298, 1992.

Boisvenue, C. and Running, S. W.: Impacts of climate change on natural forest productivity - evidence since the middle of the 20th century, Global Change Biol., 12, 862-882, doi:10.1111/j.1365-2486.2006.01134.x, 2006.

10 Bradford, J. B., Birdsey, R. A., Joyce, L. A., and Ryan, M. G.: Tree age, disturbance history, and carbon stocks and fluxes in subalpine Rocky Mountain forests, Global Change Biol., 14, 2882-2897, doi:10.1111/j.1365-2486.2008.01686.x, 2008.

Brooks, R. and Corey, A.: Hydraulic properties of porous media, in: Hydrology Paper 3, Colorado State University, Fort Collins, p. 27, 1964.

Cayan, D. R., Dettinger, M. D., Kammerdiener, S. A., Caprio, J. M., and Peterson, D. H.: Changes in the onset of spring in the Western United States, B. Am. Meteorol. Soc., 82, 399-415, doi:10.1175/1520-0477(2001)082<0399:CITOOS>2.3.CO;2, 2001.

Dahlgren, R. A., Boettinger, J. L., Huntington, G. L., and Amundson, R. G.: Soil development along an elevational transect in the western Sierra Nevada, California, Geoderma, 78, 207236, doi:10.1016/S0016-7061(97)00034-7, 1997.

Daly, C., Neilson, R., and Phillips, D.: A statistical-topographic model for mapping climatological precipitation over mountainous terrain, J. Appl. Meteorol., 33, 140-158, doi:10.1175/15200450(1994)033<0140:ASTMFM>2.0.CO;2, 1994.

Denning, A., Baron, J., Mast, M., and Arthur, M.: Hydrologic pathways and chemical composition of runoff during snowmelt in Loch Vale watershed, Rocky Mountain National Park, Colorado, USA, Water Air Soil Poll., 59, 107-123, 1991.

Dingman, S. L.: Physical Hydrology, 2nd Edn., Prentice Hall, Englewood Cliffs, NJ, 1994.

Donohue, R. J., Roderick, M. L., and McVicar, T. R.: Roots, storms and soil pores: incorporating key ecohydrological processes into Budyko's hydrological model, J. Hydrol., 436-437, 35$30 \quad$ 50, doi:10.1016/j.jhydrol.2012.02.033, 2012.

Farquhar, G. D., Von Caemmerer, S. and Berry, J. A.: A biochemical model of photosynthetic $\mathrm{CO}_{2}$ assimilation in leaves of C3 species, Planta, 149, 78-90, 1980.

Climate regime and soil storage capacity interact to effect ET

E. S. Garcia and C. L. Tague

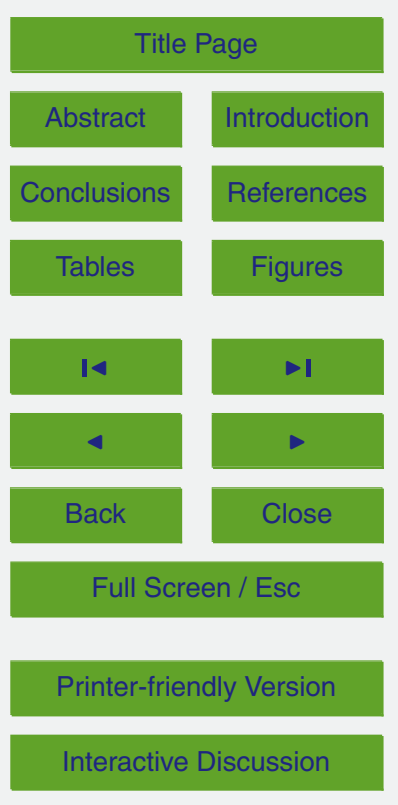


Feng, X., Vico, G., and Porporato, A.: On the effects of seasonality on soil water balance and plant growth, Water Resour. Res., 48, W05543, doi:10.1029/2011WR011263, 2012.

Flock, J.: Lichen-bryophyte distribution along a snow-cover-soil-moisture gradient, Niwot Ridge, Colorado, Arct. Alp. Res., 10, 31-47, 1978.

5 Geroy, I. J., Gribb, M. M., Marshall, H. P., Chandler, D. G., Benner, S. G., and McNamara, J. P.: Aspect influences on soil water retention and storage, Hydrol. Process., 25, 3836-3842, doi:10.1002/hyp.8281, 2011.

Gholz, H. L.: Environmental limits on aboveground net primary production, leaf area, and biomass in vegetation zones of the Pacific Northwest, Ecology, 63, 469-481, 1982.

10 Goldstein, A. H., Hultman, N. E., Fracheboud, J. M., Bauer, M. R., Panek, J. A., Xu, M., Qi, Y., Guenther, A. B., and Baugh, W.: Effects of climate variability on the carbon dioxide, water, and sensible heat fluxes above a ponderosa pine plantation in the Sierra Nevada (CA), Agr. Forest Meteorol., 101, 113-129, doi:10.1016/S0168-1923(99)00168-9, 2000.

Goulden, M. L., Anderson, R. G., Bales, R. C., Kelly, A. E., Meadows, M., and Winston, G. C.: 15 Evapotranspiration along an elevation gradient in California's Sierra Nevada, J. Geophys. Res., 117, G03028, doi:10.1029/2012JG002027, 2012.

Grier, C. C. and Logan, R. S.: Old-growth Pseudotsuga menziesii communities of a western Oregon watershed: biomass distribution and production budgets, Ecol. Monogr., 47, 373400, 1977.

20 Hamlet, A. F., Mote, P. W., Clark, M. P., and Lettenmaier, D. P.: Effects of temperature and precipitation variability on snowpack trends in the western United States*, J. Climate, 18, 4545-4561, doi:10.1175/JCLI3538.1, 2005.

Hamlet, A. F., Mote, P. W., Clark, M. P., and Lettenmaier, D. P.: Twentieth-century trends in runoff, evapotranspiration, and soil moisture in the western United States ${ }^{*}$, J. Climate, 20, 1468-1486, doi:10.1175/JCLI4051.1, 2007.

Hicke, J. A., Allen, C. D., Desai, A. R., Dietze, M. C., Hall, R. J., Ted Hogg, E. H., Kashian, D. M., Moore, D., Raffa, K. F., Sturrock, R. N., and Vogelmann, J.: Effects of biotic disturbances on forest carbon cycling in the United States and Canada, Global Change Biol., 18, 7-34, doi:10.1111/j.1365-2486.2011.02543.x, 2012.

30 Homer, C., Dewitz, J., Fry, J., Coan, M., Hossain, N., Larson, C., Herold, N., Mckerrow, A., Vandriel, J. N., and Wickham, J.: Completion of the 2001 national land cover database for the conterminous United States, Photogramm. Eng. Rem. S., 73, 337-341, 2007.

HESSD

$11,2277-2319,2014$

Climate regime and

soil storage capacity

interact to effect ET

E. S. Garcia and

C. L. Tague

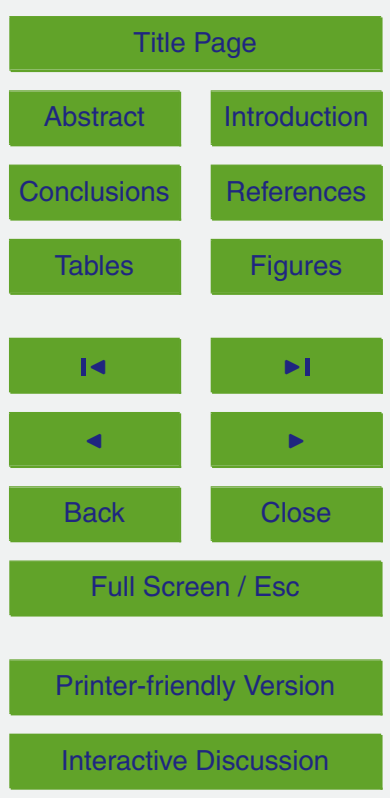


Hu, J., Moore, D. J. P., Burns, S. P., and Monson, R. K.: Longer growing seasons lead to less carbon sequestration by a subalpine forest, Global Change Biol., 16, 771-783, doi:10.1111/j.1365-2486.2009.01967.x, 2010. =

Hudiburg, T., Law, B., Turner, D. P., Campbell, J., Donato, D., and Duane, M.: Carbon dynamics 5 of Oregon and northern California forests and potential land-based carbon storage., Ecol. Appl., 19, 163-180, 2009.

Hwang, T., Song, C., Bolstad, P. V., and Band, L. E.: Downscaling real-time vegetation dynamics by fusing multi-temporal MODIS and Landsat NDVI in topographically complex terrain, Remote Sens. Environ., 115, 2499-2512, doi:10.1016/j.rse.2011.05.010, 2011.

10 Isaac, V. and van Wijngaarden, W. A.: Surface water vapor pressure and temperature trends in North America during 1948-2010, J. Climate, 25, 3599-3609, doi:10.1175/JCLI-D-11$00003.1,2012$.

Jarvis, P.: The interpretation of the variations in leaf water potential and stomatal conductance found in canopies in the field, Philos. T. Roy. Soc. B, 273, 593-601, doi:10.1098/rstb.1976.0035, 1976.

Jeton, A. E., Dettinger, M. D., and LaRue Smith, J.: Potential effects of climate change on streamflow, eastern and western slopes of the Sierra Nevada, California and Nevada, WaterResources Investigations Report 95-4260, US Geological Survey, Sacramento California, 44 pp., 1996.

20 Knowles, N., Dettinger, M. D., and Cayan, D. R.: Trends in snowfall vs. rainfall in the western United States, J. Climate, 19, 4545-4559, doi:10.1175/JCLI3850.1, 2006.

Landsberg, J. and Waring, R.: A generalised model of forest productivity using simplified concepts of radiation-use efficiency, carbon balance and partitioning, Forest Ecol. Manage., 95, 209-228, 1997.

Litaor, M. I., Williams, M., and Seastedt, T. R.: Topographic controls on snow distribution, soil moisture, and species diversity of herbaceous alpine vegetation, Niwot Ridge, Colorado, J. Geophys. Res., 113, G02008, doi:10.1029/2007JG000419, 2008.

Littell, J. S., Peterson, D. L., and Tjoelker, M.: Douglas-Fir growth in mountain ecosystems?: water limits tree growth from stand to region, Ecol. Monogr., 78, 349-368, 2008.

30 Littell, J. S., McKenzie, D., Peterson, D., and Westerling, A.: Climate and wildfire area burned in western US ecoprovinces, 1916-2003, Ecol. Appl., 19, 1003-1021, doi:10.1890/07-1183.1, 2009.
HESSD

$11,2277-2319,2014$

Climate regime and soil storage capacity

interact to effect ET

E. S. Garcia and

C. L. Tague

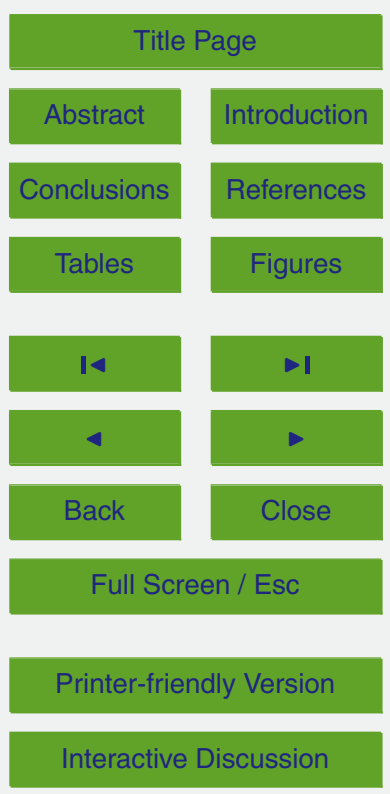


Loudermilk, E. L., Scheller, R. M., Weisberg, P. J., Yang, J., Dilts, T. E., Karam, S. L., and Skinner, C.: Carbon dynamics in the future forest: the importance of long-term successional legacy and climate-fire interactions, Global Change Biol., 19, 3502-3515, doi:10.1111/gcb.12310, 2013.

5 Lundquist, J. D.: How evaporative water losses vary between wet and dry water years as a function of elevation in the Sierra Nevada, California, and critical factors for modeling, Water Resour. Res., 47, W0OH09, doi:10.1029/2010WR010050, 2011.

Lundquist, J. D., Dickerson-Lange, S. E., Lutz, J. A., and Cristea, N. C.: Lower forest density enhances snow retention in regions with warmer winters: a global framework developed from plot-scale observations and modeling, Water Resour. Res., 49, 1-15, doi:10.1002/wrcr.20504, 2013.

McGuire, K. J., Weiler, M., and McDonnell, J. J.: Integrating tracer experiments with modeling to assess runoff processes and water transit times, Adv. Water Resour., 30, 824-837, doi:10.1016/j.advwatres.2006.07.004, 2007.

Molotch, N. P., Brooks, P. D., Burns, S. P., Litvak, M., Monson, R. K., Mcconnell, J. R., and Musselman, K.: Ecohydrological controls on snowmelt partitioning in mixed-conifer sub-alpine forests, Ecohydrology, 2, 129-142, doi:10.1002/eco.48, 2009.

Monteith, J.: Evaporation and Environment, in: Symp. Soc. Exp. Biology, Cambridge University Press, New York, 205-234, 1965.

20 Moore, I. D., Grayson, R. B., and Ladson, A. R.: Digital terrain modelling?: a review of hydrological, geomorphological, and biological applications, Hydrol. Process., 5, 3-30, 1991.

Mote, P. W.: Climate-driven variability and trends in mountain snowpack in western North America*, J. Climate, 19, 6209-6220, doi:10.1175/JCLI3971.1, 2006.

Mote, P. W., Hamlet, A. F., Clark, M. P., and Lettenmaier, D. P.: Declining mountain snowpack in western North America*, B. Am. Meteorol. Soc., 86, 39-49, doi:10.1175/BAMS-86-1-39, 2005.

Muggeo, V. M. R.: Estimating regression models with unknown break-points, Stat. Med., 22, 3055-71, doi:10.1002/sim.1545, 2003.

Nash, J. E. and Sutcliffe, J.: River flow forecasting through conceptual models - Part 1: A discussion of principles, J. Hydrol., 10, 282-290, 1970.

Porporato, A., Daly, E., and Rodriguez-Iturbe, I.: Soil water balance and ecosystem response to climate change, Am. Nat., 164, 625-632, 2004. 
Running, S. and Nemani, R.: Extrapolation of synoptic meteorological data in mountainous terrain and its use for simulating forest evapotranspiration and photosynthesis, Can. J. Forest Res., 17, 472-483, 1987.

Smith, T. J., McNamara, J. P., Flores, A. N., Gribb, M. M., Aishlin, P. S., and Benner, S. G.: 5 Small soil storage capacity limits benefit of winter snowpack to upland vegetation, Hydrol. Process., 25, 3858-3865, doi:10.1002/hyp.8340, 2011.

Stewart, I. T., Cayan, D. R., and Dettinger, M. D.: Changes toward earlier streamflow timing across western North America, J. Climate, 18, 1136-1155, doi:10.1175/JCLI3321.1, 2005.

Tague, C.: Assessing climate change impacts on alpine stream-flow and vegetation water use: mining the linkages with subsurface hydrologic processes, Hydrol. Process., 23, 1815-1819, doi:10.1002/hyp.7288, 2009.

Tague, C. and Band, L.: RHESSys: regional hydro-ecologic simulation system-an objectoriented approach to spatially distributed modeling of carbon, water, and nutrient cycling, Earth Interact., 8, 1-42, doi:10.1175/1087-3562(2004)8<1:RRHSSO>2.0.CO;2, 2004.

Tague, C. and Heyn, K.: Topographic controls on spatial patterns of conifer transpiration and net primary productivity under climate warming in mountain ecosystems, Ecohydrology, 554, 541-554, doi:10.1002/eco, 2009.

Tague, C. and Peng, H.: The sensitivity of forest water use to the timing of precipitation and snowmelt recharge in the California Sierra: implications for a warming climate, J. Geophys.

20 Res.-Biogeo., 118, 1-13, doi:10.1002/jgrg.20073, 2013.

Thornton, P. E.: Description of a numerical simulation model for predicting the dynamics of energy, water, carbon, and nitrogen in a terrestrial ecosystem, University of Montana, Missoula, MT, 280 pp., 1998.

Thornton, P. E. and Rosenbloom, N. A.: Ecosystem model spin-up: estimating steady state conditions in a coupled terrestrial carbon and nitrogen cycle model, Ecol. Model., 189, 2548, doi:10.1016/j.ecolmodel.2005.04.008, 2005.

Thornton, P. E., Thornton, M., Mayer, B., Wilhelmi, N., Wei, Y., and Cook, R.: Daymet: Daily surface weather on a $1 \mathrm{~km}$ grid for North America, 1980-2012, Oak Ridge Natl. Lab. Distrib. Act. Arch. Cent., Oak Ridge, Tennessee, USA, doi:10.3334/ORNLDAAC/Daymet_V2, 2012.

30 Trujillo, E., Molotch, N. P., Goulden, M. L., Kelly, A. E., and Bales, R. C.: Elevationdependent influence of snow accumulation on forest greening, Nat. Geosci., 5, 705-709, doi:10.1038/ngeo1571, 2012.

\section{HESSD}

11, 2277-2319, 2014

Climate regime and soil storage capacity

interact to effect ET

E. S. Garcia and

C. L. Tague

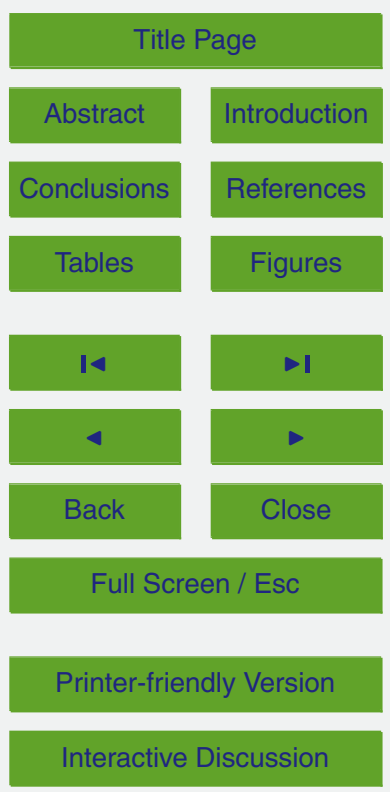


Van Mantgem, P. J., Stephenson, N. L., Byrne, J. C., Daniels, L. D., Franklin, J. F., Fulé, P. Z., Harmon, M. E., Larson, A. J., Smith, J. M., Taylor, A. H., and Veblen, T. T.: Widespread increase of tree mortality rates in the western United States, Science, 323, 521-4, doi:10.1126/science.1165000, 2009.

5 Van Tuyl, S., Law, B. E., Turner, D. P., and Gitelman, A. I.: Variability in net primary production and carbon storage in biomass across Oregon forests - an assessment integrating data from forest inventories, intensive sites, and remote sensing, Forest Ecol. Manage., 209, 273-291, doi:10.1016/j.foreco.2005.02.002, 2005.

Varhola, A., Coops, N. C., Bater, C. W., Teti, P., Boon, S., and Weiler, M.: The influence of ground- and lidar-derived forest structure metrics on snow accumulation and ablation in disturbed forests, Can. J. Forest Res., 40, 812-821, doi:10.1139/X10-008, 2010.

Viola, F., Daly, E., Vico, G., Cannarozzo, M., and Porporato, A.: Transient soil-moisture dynamics and climate change in Mediterranean ecosystems, Water Resour. Res., 44, 1-12, doi:10.1029/2007WR006371, 2008.

Voepel, H., Ruddell, B., Schumer, R., Troch, P. A., Brooks, P. D., Neal, A., Durcik, M., and Sivapalan, M.: Quantifying the role of climate and landscape characteristics on hydrologic partitioning and vegetation response, Water Resour. Res., 47, 1-13, doi:10.1029/2010WR009944, 2011.

Waichler, S. R., Wemple, B. C., and Wigmosta, M. S.: Simulation of water balance and forest treatment effects at the H. J. Andrews Experimental Forest, Hydrol. Process., 19, 3177-3199, doi:10.1002/hyp.5841, 2005.

Winkler, R., Boon, S., Zimonick, B., and Spittlehouse, D.: Snow accumulation and ablation response to changes in forest structure and snow surface albedo after attack by mountain pine beetle, Hydrol. Process., 28, 197-209, doi:10.1002/hyp.9574, 2014.

Climate regime and soil storage capacity

interact to effect ET

E. S. Garcia and

C. L. Tague

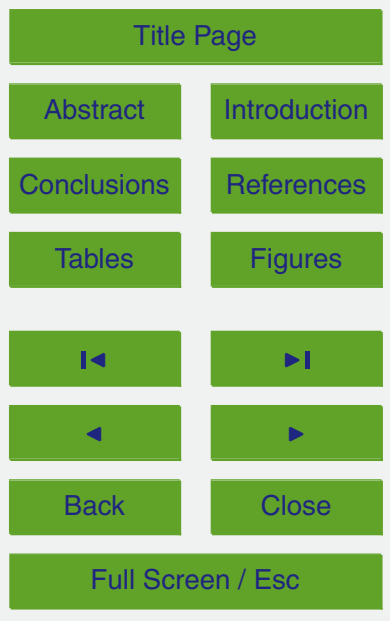

Printer-friendly Version

Interactive Discussion 


\section{HESSD}

11, 2277-2319, 2014

Climate regime and soil storage capacity interact to effect ET

E. S. Garcia and C. L. Tague

Table 1. Explanatory variables.

\begin{tabular}{ll}
\hline Abbreviation & Definition \\
\hline$P$ & Total annual precipitation \\
$T_{\text {AMJ }}$ & Average daily temperature for April, May, June \\
$R_{75}$ & Day of water year that $75 \%$ of soil water recharge occurs \\
AWC & Available water capacity of soil (field capacity-wilting point) \\
\hline
\end{tabular}

Title Page

Abstract

Introduction

Conclusions

References

Tables

Figures

14

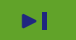

4

Back

Close

Full Screen / Esc

Printer-friendly Version

Interactive Discussion 
Table 2. Basin topography, geology, vegetation and climate characteristics. Climate descriptions are averaged over total available climate record (duration noted in table).

\begin{tabular}{|c|c|c|c|}
\hline Watershed & CO-ROC & OR-CAS & CA-SIER \\
\hline Location & Colorado & Oregon & California \\
\hline $\begin{array}{l}\text { US Geological Survey } \\
\text { gage number }\end{array}$ & 06733000 & 14161500 & 10343500 \\
\hline Geology & $\begin{array}{l}\text { Holocene glacial till, rock; } \\
\text { Precambrian gneiss, } \\
\text { granite }\end{array}$ & Western Cascade basalt & $\begin{array}{l}\text { Sierra granite, with } \\
\text { Miocene andesite cap }\end{array}$ \\
\hline Elevation range (m) & $1470-4345$ & $410-1630$ & $1800-2650$ \\
\hline Drainage Area $\left(\mathrm{km}^{2}\right)$ & 350 & 64 & 26 \\
\hline $\begin{array}{l}\text { Topographic Wetness } \\
\text { Index- Mean (Std Dev) }\end{array}$ & $7.0(1.9)$ & $6.6(1.7)$ & $7.9(1.8)$ \\
\hline Climate record & 1980-2008 & 1958-2008 & 1960-2000 \\
\hline $\begin{array}{l}\text { Mean Annual } \\
\text { Precipitation (mm) }\end{array}$ & 1000 & 2250 & 850 \\
\hline $\begin{array}{l}\text { Annual Precipitation } \\
\text { as snow (\%) }\end{array}$ & 64 & 29 & 55 \\
\hline $\begin{array}{l}\text { Precipitation received } \\
\text { in Growing Season (\%) }\end{array}$ & 46 & 21 & 19 \\
\hline $\begin{array}{l}\text { Min/Max winter } T \\
(\mathrm{JFM})(\mathrm{OC})\end{array}$ & $-12.1 /-0.02$ & $-0.9 / 5.2$ & $-9.5 / 3.7$ \\
\hline $\begin{array}{l}\text { Min/Max spring } T \\
(\mathrm{AMJ})(\mathrm{oC})\end{array}$ & $-2.7 / 10.9$ & $4.0 / 14.0$ & $-2.5 / 13.8$ \\
\hline Vegetation & $\begin{array}{l}\text { Subalpine fir, aspen, } \\
\text { meadows, shrub }\end{array}$ & $\begin{array}{l}\text { Douglas-fir, } \\
\text { Western Hemlock }\end{array}$ & $\begin{array}{l}\text { Mixed Conifer, Jeffrey } \\
\text { and Lodgepole Pine }\end{array}$ \\
\hline Mean basin LAI & 3.5 & 9.0 & 4.1 \\
\hline $\begin{array}{l}\text { Annual NPP range for } \\
\text { calibration }\left(\mathrm{gCm}^{-2} \mathrm{yr}^{-1}\right)\end{array}$ & $280-520$ & $620-1100$ & $450-800$ \\
\hline $\begin{array}{l}\text { Literature sources used } \\
\text { to bound annual } \\
\text { NPP range }\end{array}$ & $\begin{array}{l}\text { Arthur and Fahey (1992), } \\
\text { Bradford et al. (2008) }\end{array}$ & $\begin{array}{l}\text { Grier and Logan (1977) } \\
\text { Gholz (1982) }\end{array}$ & $\begin{array}{l}\text { Hudiburg et al. (2009), } \\
\text { Goulden et al. (2012) }\end{array}$ \\
\hline
\end{tabular}

*Values reported as gross primary productivity, converted to NPP using RHESSys calculated values of respiration.

\section{HESSD}

$11,2277-2319,2014$

Climate regime and soil storage capacity interact to effect ET
E. S. Garcia and C. L. Tague

\section{Title Page}

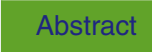

Introduction

Conclusions

References

Tables

Figures

14

4

Back

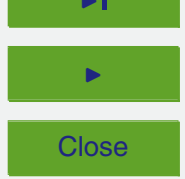

Full Screen / Esc

Printer-friendly Version

Interactive Discussion 
Table 3. Calibrated average basin soil parameters used for linear regression analyses between annual ET and $P, R_{75}$, and $T_{\mathrm{AMJ}}$.

\begin{tabular}{lllllllll}
\hline Watershed & $\begin{array}{l}m \\
\left(\mathrm{~m}^{-1}\right)\end{array}$ & $\begin{array}{l}K \\
\left(\mathrm{md}^{-1}\right)\end{array}$ & $\begin{array}{l}b \\
(-)\end{array}$ & $\begin{array}{l}\varphi_{\mathrm{ae}} \\
\left(\mathrm{m} \mathrm{H}_{2} \mathrm{O}\right)\end{array}$ & $\begin{array}{l}\mathrm{gw}_{1} \\
(-)\end{array}$ & $\begin{array}{l}\mathrm{gw}_{2} \\
\left(\mathrm{md}^{-1}\right)\end{array}$ & $\begin{array}{l}Z_{r} \\
(\mathrm{~m})\end{array}$ & $\begin{array}{l}\text { AWC } \\
(\mathrm{mm})\end{array}$ \\
\hline CO-ROC & 0.05 & 9500 & 0.2 & 0.05 & 0.2 & 0.7 & 1.4 & 400 \\
OR-CAS & 0.1 & 300 & 0.1 & 0.01 & 0.15 & 0.3 & 1.0 & 230 \\
CA-SIER & 0.5 & 2300 & 0.2 & 0.007 & 0.3 & 0.3 & 1.7 & 270 \\
\hline
\end{tabular}

HESSD

11, 2277-2319, 2014

Climate regime and soil storage capacity interact to effect ET

E. S. Garcia and C. L. Tague

\section{Title Page}

Abstract Introduction

Conclusions

References

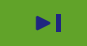

4 
Table 4. Statistics for ET predictors based on linear regression models.

\begin{tabular}{lllll}
\hline Watershed & & CO-ROC & OR-CAS & CA-SIER \\
\hline Precipitation & $p$ value & $<0.001$ & $>0.05$ & $<0.001$ \\
$(P)$ & $r^{2}$ & 0.88 & 0.24 & 0.72 \\
& slope & 0.7 & 0.2 & 0.5 \\
Timing $\left(R_{75}\right)$ & $p$ value & 0.001 & $>0.05$ & 0.001 \\
& $r^{2}$ & 0.43 & 0.21 & 0.36 \\
& slope & 2.2 & 0.3 & 1.8 \\
Temperature & $p$ value & $<0.01$ & 0.05 & 0.01 \\
$T_{\text {AMJ }}$ & $r^{2}$ & 0.42 & 0.12 & 0.20 \\
Soil capacity & $p$ value & -0.001 & -0.3 & -0.3 \\
(AWC) & $r^{2}$ & 0.43 & 0.001 & 0.001 \\
& slope & 0.1 & 0.53 & 0.11 \\
\hline
\end{tabular}

HESSD

11, 2277-2319, 2014

Climate regime and soil storage capacity interact to effect ET

E. S. Garcia and C. L. Tague

Title Page

Abstract Introduction

Conclusions References

Tables Figures

14

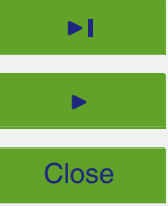

Back

Full Screen / Esc

Printer-friendly Version

Interactive Discussion 


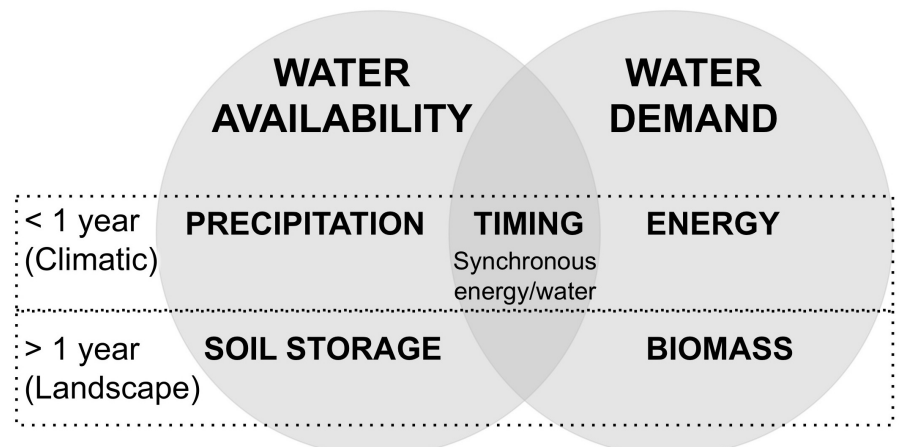

Fig. 1. Conceptual model of evapotranspiration (ET) groups its controls into categories of water availability and demand. These controls influence ET sub-annually and at multi-annual timescales. The duration of overlap between climatic demand and availability is an important control of ET in Western US catchments.

\section{HESSD}

11, 2277-2319, 2014

Climate regime and soil storage capacity

interact to effect ET

E. S. Garcia and C. L. Tague

\section{Title Page}

Abstract Introduction

Conclusions References

Tables Figures

14

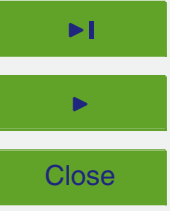

Back

Full Screen / Esc

Printer-friendly Version

Interactive Discussion 

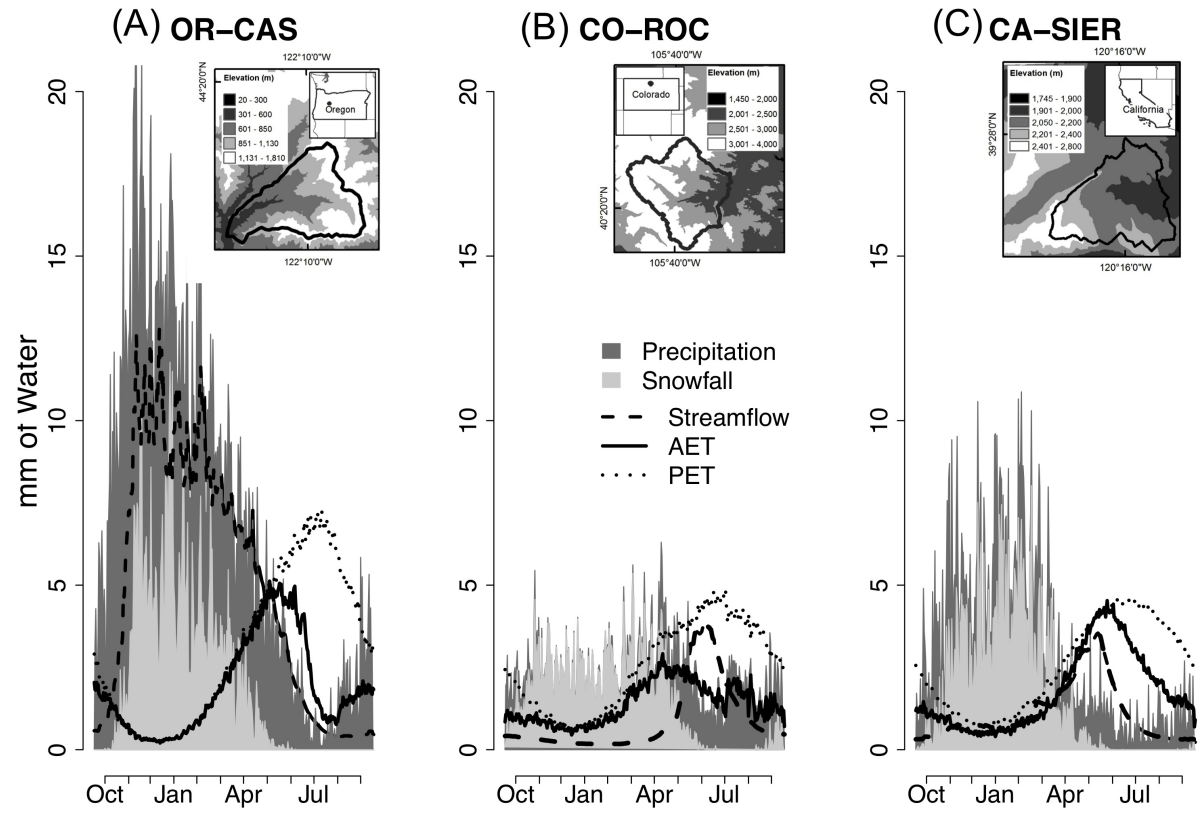

Climate regime and soil storage capacity interact to effect ET
E. S. Garcia and C. L. Tague

Fig. 2. Locations and average daily water fluxes averaged over 1980-2000 for three study watersheds.

\section{Title Page}

Abstract Introduction

Conclusions References

Tables Figures

14

4

Back

Full Screen / Esc

Printer-friendly Version

Interactive Discussion 

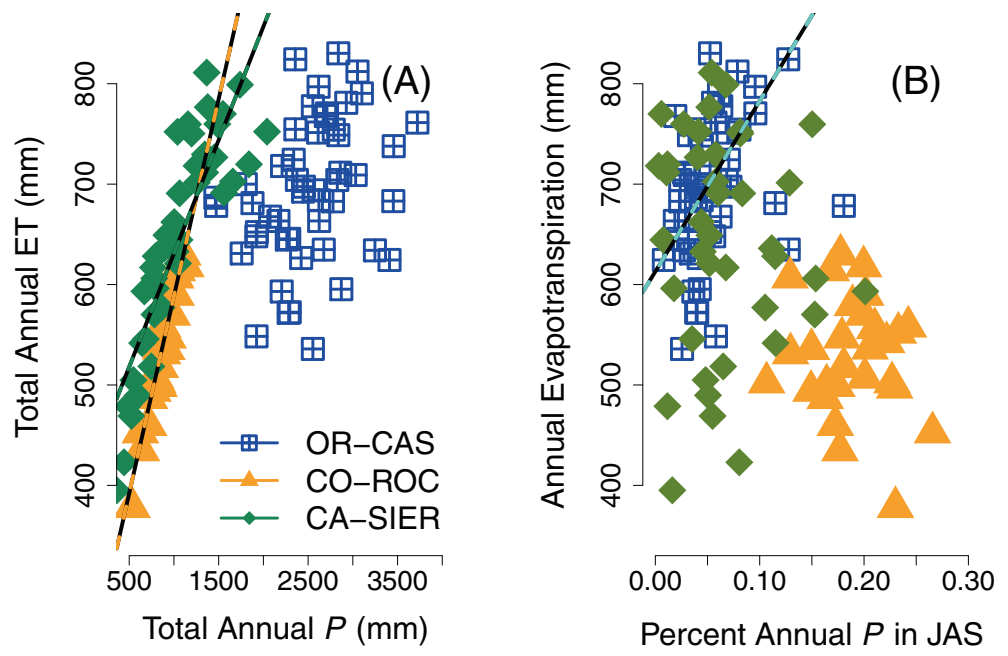

\section{HESSD}

11, 2277-2319, 2014

Climate regime and soil storage capacity interact to effect ET

E. S. Garcia and C. L. Tague

\section{Title Page}

Abstract Introduction

Conclusions References

Tables Figures

14

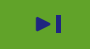

Fig. 3. (A) Total annual ET increases with total annual precipitation. (B) Though annual $P$ is not significantly related to annual ET in OR-CAS, a significant relationship exists between summer (JAS) precipitation and annual ET.

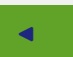

Back

Full Screen / Esc

Printer-friendly Version

Interactive Discussion 


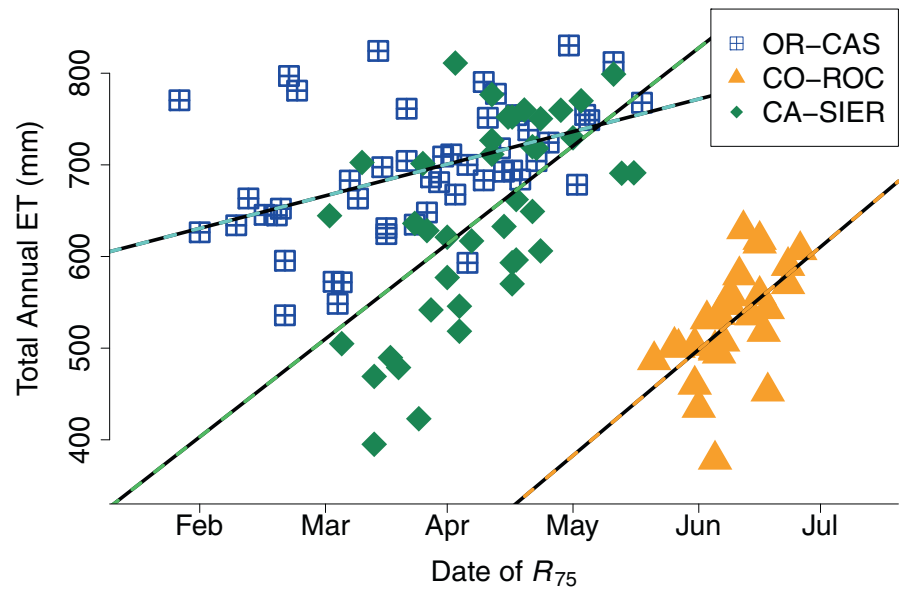

Fig. 4. Later occurrence of soil moisture recharge $\left(R_{75}\right)$ is significantly correlated with increased annual ET in all study watersheds.

\section{HESSD}

11, 2277-2319, 2014

Climate regime and soil storage capacity interact to effect ET

E. S. Garcia and C. L. Tague

\section{Title Page}

Abstract Introduction

Conclusions References

Tables Figures

14

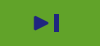

4

Back

Close

Full Screen / Esc

Printer-friendly Version

Interactive Discussion 

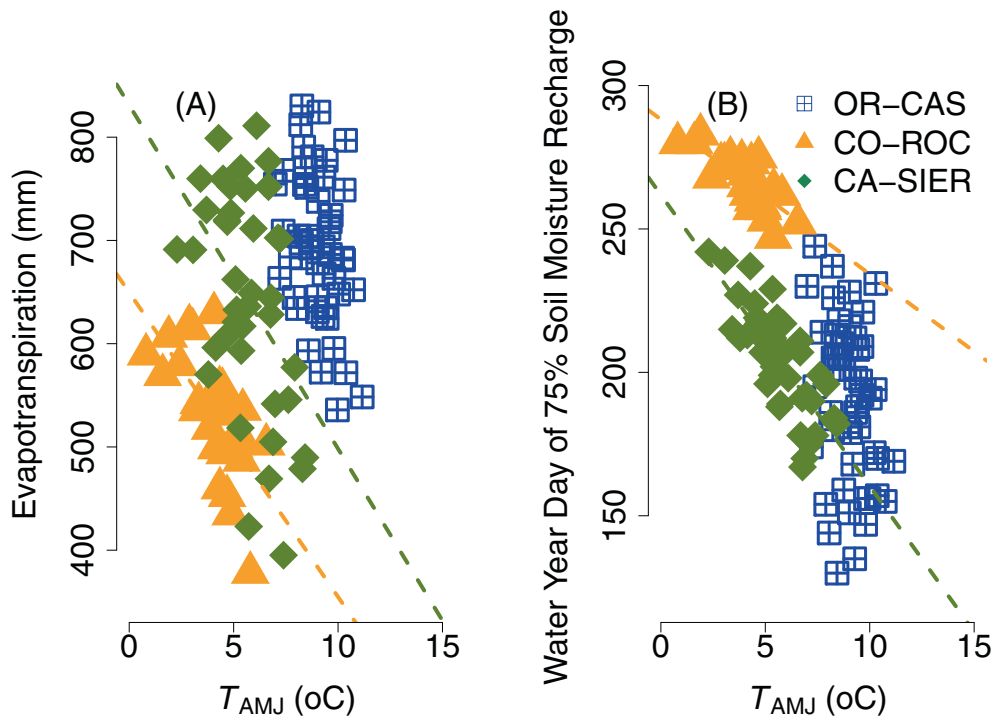

\section{HESSD}

11, 2277-2319, 2014

Climate regime and soil storage capacity interact to effect ET

E. S. Garcia and C. L. Tague

\section{Title Page}

Abstract Introduction

Conclusions References

Tables Figures

14

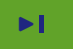

Fig. 5. (A) Warmer spring temperatures are correlated with lower total annual ET and (B) earlier occurrence of soil moisture recharge in the two snow-dominated watersheds.

\section{Close}

Full Screen / Esc

Printer-friendly Version 


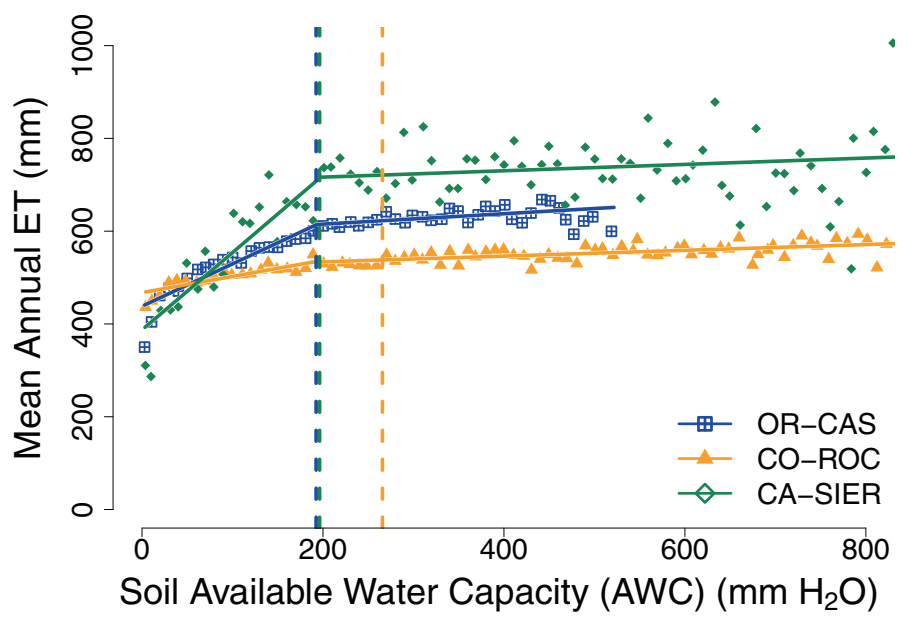

\section{HESSD}

11, 2277-2319, 2014

Climate regime and soil storage capacity interact to effect ET

E. S. Garcia and C. L. Tague

\section{Title Page}

Abstract

Conclusions

Tables

14

4

Back
Introduction

References

Figures

Fig. 6. Each point represents mean annual ET from WY 1985-2000 for a physically feasible mean basin soil available water capacity (AWC). Vertical lines represent the calculated breakpoint in the nonlinear relationship between long-term ET and AWC for each basin.

\section{Full Screen / Esc}

Printer-friendly Version 


\section{HESSD}

11, 2277-2319, 2014

OR-CAS

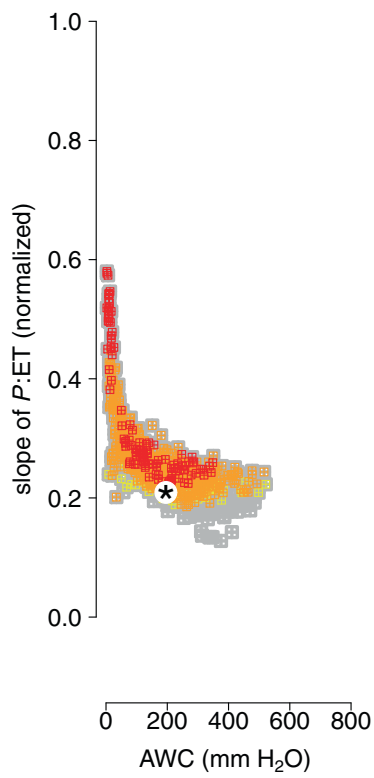

CO-ROC

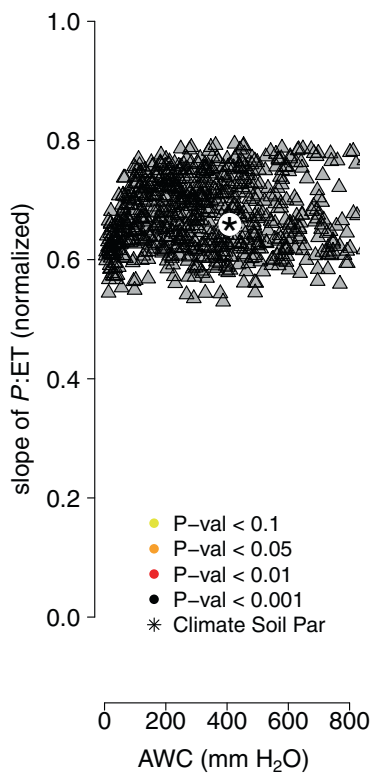

CA-SIER

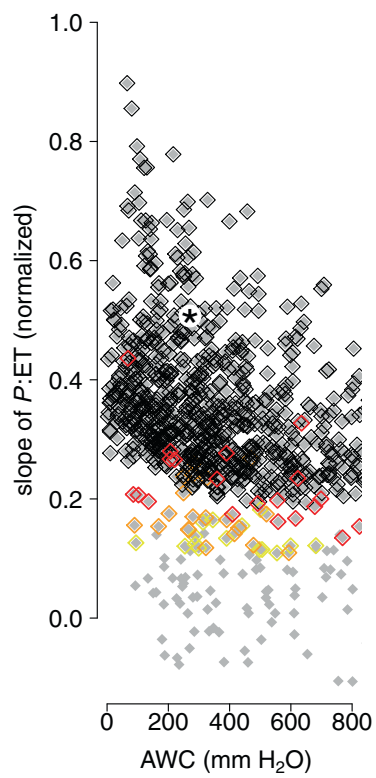

Climate regime and soil storage capacity interact to effect ET

E. S. Garcia and C. L. Tague

\section{Title Page}

Abstract Introduction

Conclusions References

Tables Figures

14 $>1$

$\triangleleft$

Back

Close

\section{Full Screen / Esc}

Printer-friendly Version

Interactive Discussion 


\section{HESSD}

11, 2277-2319, 2014
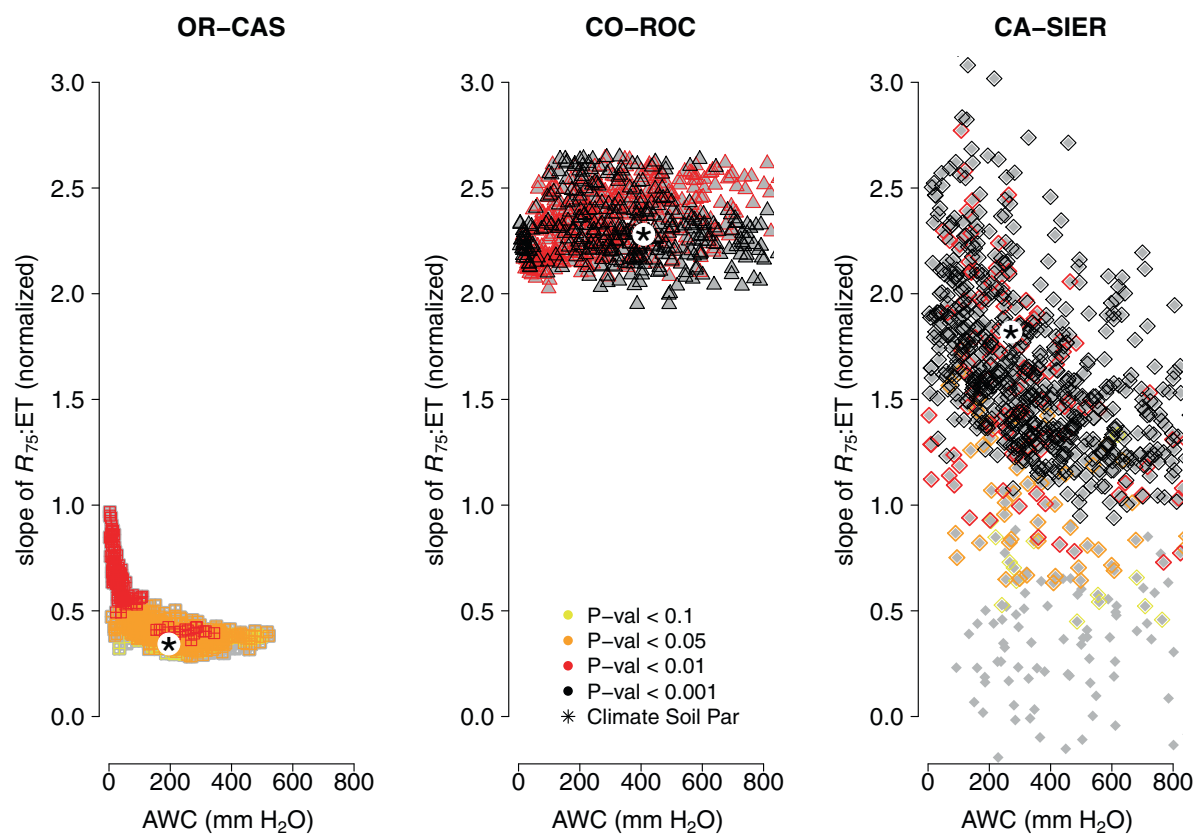

Climate regime and soil storage capacity interact to effect ET

E. S. Garcia and C. L. Tague

\section{Title Page}

Abstract Introduction

Conclusions References

Tables Figures

14

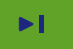

4

Back

Close

\section{Full Screen / Esc}

Printer-friendly Version

Interactive Discussion 


\section{HESSD}

$11,2277-2319,2014$

OR-CAS

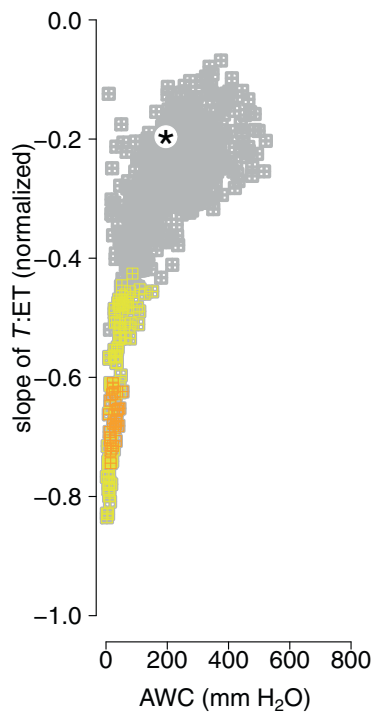

CO-ROC

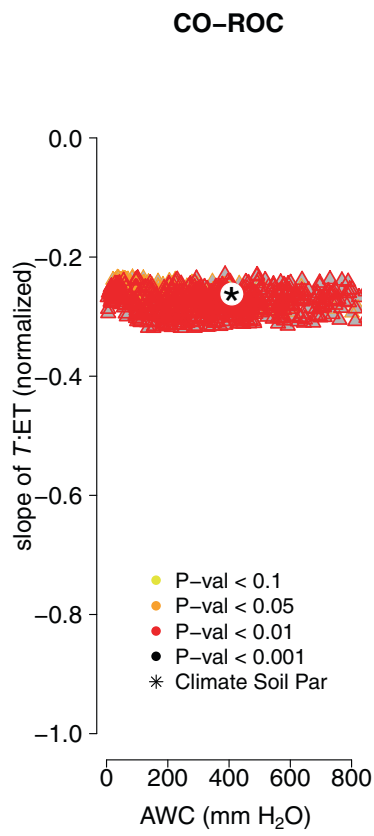

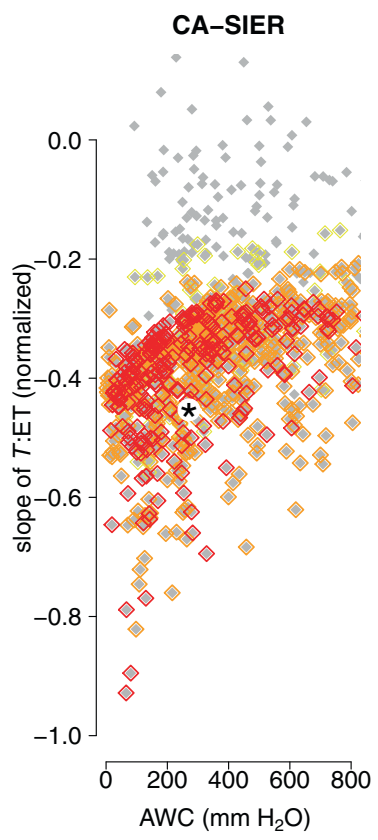

Fig. 9. Slopes of the linear regression model calculated for $T_{\mathrm{AMJ}}$ against ET across all watersheds' soil AWCs. Note that the slopes are normalized to facilitate inter-basin comparison. "Climate Soil Par" represents the soil parameter set used for model results presented in Figs. 3-5 and Sects. 3.1-3.3.
Climate regime and soil storage capacity interact to effect ET

E. S. Garcia and C. L. Tague

\section{Title Page}

Abstract Introduction

Conclusions References

Tables Figures

14 $>1$

4

Back

Close

Full Screen / Esc

Printer-friendly Version

Interactive Discussion 